\title{
The impact of shipping emissions on air pollution in the greater North Sea region - Part 2: Scenarios for 2030
}

\author{
V. Matthias ${ }^{1}$, A. Aulinger ${ }^{1}$, A. Backes ${ }^{1}$, J. Bieser ${ }^{1}$, B. Geyer ${ }^{1}$, M. Quante $^{1}$, and M. Zeretzke ${ }^{2}$ \\ ${ }^{1}$ Helmholtz-Zentrum Geesthacht, Institute of Coastal Research, Max-Planck-Straße 1, 21502 Geesthacht, Germany \\ ${ }^{2}$ DNV-GL, Brooktorkai 18, 20457 Hamburg, Germany \\ Correspondence to: V. Matthias (volker.matthias@hzg.de)
}

Received: 29 January 2015 - Published in Atmos. Chem. Phys. Discuss.: 16 April 2015

Revised: 2 September 2015 - Accepted: 18 October 2015 - Published: 22 January 2016

\begin{abstract}
Scenarios for future shipping emissions in the North Sea have been developed in the framework of the Clean North Sea Shipping project. The effects of changing $\mathrm{NO}_{x}$ and $\mathrm{SO}_{2}$ emissions were investigated with the CMAQ chemistry transport model for the year 2030 in the North Sea area. It has been found that, compared to today, the contribution of shipping to the $\mathrm{NO}_{2}$ and $\mathrm{O}_{3}$ concentrations will increase due to the expected enhanced traffic by more than 20 and $5 \%$, respectively, by 2030 if no regulation for further emission reductions is implemented in the North Sea area. $\mathrm{PM}_{2.5}$ will decrease slightly because the sulfur contents in ship fuels will be reduced as international regulations foresee. The effects differ largely between regions, seasons and date of the implementation of stricter regulations for $\mathrm{NO}_{x}$ emissions from newly built ships.
\end{abstract}

\section{Introduction}

Shipping is an important contributor to air pollution in coastal areas. More than $90 \%$ of global trade is done with ships. The total global transport work by ships (in ton miles) has been tripled since the mid-1980s (Smith et al., 2014), corresponding to an average growth rate of $4 \%$ p.a., and the forecasts for the future are of the same order of magnitude (Smith et al., 2014). The North Sea is one of the areas with the highest ship densities in the world. Europe's three biggest harbours in Rotterdam, Hamburg, and Antwerp are located in the North Sea region. At any time, about 3000 ships are sailing in the North Sea (Aulinger et al., 2016). The steady increase in the number and size of ships leads to an increasing contribution of ships to air pollution in North Sea coastal areas (Matthias et al., 2010; Hammingh et al., 2012; Jalkanen et al., 2012; Aulinger et al., 2016). Compared to other modes of transport like trucks or trains, big container ships or tankers are very efficient in terms of fuel use per ton mile. However, $\mathrm{NO}_{x}, \mathrm{SO}_{2}$ and $\mathrm{PM}$ emissions are comparably high because of less strict regulations for the emissions of these pollutants from ships. This problem was already recognised years ago, leading to stricter regulations in some areas, the so-called emission control areas (ECAs). These regulations are the results of an agreement within the International Maritime Organization (IMO) and they are laid down in MARPOL Annex VI (International Maritime Organization, 2008). The EU has implemented these rules in their directives 1999/32/EC (European Union, 1999) and 2012/33/EU (European Union, 2012) for the North and Baltic seas, which are sulfur emission control areas (SECAs). This means that the fuel burned in these areas must not contain more than $0.1 \%$ sulfur (S) (until 31 December 2014, $1.0 \% \mathrm{~S}$ ). If fuels with higher sulfur content are used, the exhaust gas has to be cleaned until it does not contain more sulfur than exhaust gas from a low-sulfur fuel. As a consequence, ships use low-sulfur fuels or installed scrubbers on board that clean the exhaust gas from sulfur and other contaminants. Outside SECAs, the allowed sulfur content in ship fuels is currently at $3.5 \%$, but it will be reduced to $0.5 \%$ in 2020 or 2025 at the latest. The exact date will be decided in 2018, when the availability of ship fuel containing less than $0.5 \% \mathrm{~S}$ will be reviewed.

Nitrogen oxide emissions from ships are also regulated in MARPOL Annex VI. Since the year 2000 the $\mathrm{NO}_{x}$ limits for ships built after 1 January 2000 have been $17 \mathrm{~g} \mathrm{kWh}^{-1}$ $\mathrm{NO}_{x}$ (Tier I regulation) for slow-speed engines $(<130$ 
revolutions per minute (rpm)) and $9.8 \mathrm{~g} \mathrm{kWh}^{-1} \mathrm{NO}_{x}$ for high-speed engines $(>2000 \mathrm{rpm})$. A power law following $45 \mathrm{rpm}^{-0.2} \mathrm{~g} \mathrm{kWh}^{-1} \mathrm{NO}_{x}$ sets the maximum emissions at intermediate engine speeds. In 2010 the second step (Tier II) of the $\mathrm{NO}_{x}$ regulations came into force with an emission factor of $14.4 \mathrm{~g} \mathrm{kWh}^{-1} \mathrm{NO}_{x}$ for new ships with slowspeed engines, for high-speed engines, $7.7 \mathrm{~g} \mathrm{kWh}^{-1} \mathrm{NO}_{x}$, and for engines in between, $44 \mathrm{rpm}^{-0.23} \mathrm{~g} \mathrm{kWh}^{-1} \mathrm{NO}_{x}$. The third step (Tier III), where $\mathrm{NO}_{x}$ limits will be further reduced to $3.4 \mathrm{~g} \mathrm{kWh}^{-1} \mathrm{NO}_{x}\left(2.0 \mathrm{~g} \mathrm{kWh}^{-1} \mathrm{NO}_{x}\right.$ for high-speed engines, $9 \mathrm{rpm}^{-0.2} \mathrm{~g} \mathrm{kWh}^{-1} \mathrm{NO}_{x}$ for engines in between), is planned for 2016 for the ECAs around North America. However, this will only be applied to new ships sailing in designated ECAs, while Tier I and Tier II represent global limits. The North Sea and the Baltic Sea are under discussion to become such an ECA for $\mathrm{NO}_{x}$. However, Tier III rules will only be valid for ships built after the designation date (International Maritime Organization, Marine Environment Protection Committee, 2014). At present, it is unclear when this date will be.

In the Clean North Sea Shipping (CNSS) European project different technologies capable of reducing air emissions from ships in the North Sea were investigated. Among them are scrubbers that reduce sulfur emissions, catalysts that reduce $\mathrm{NO}_{x}$ emissions, and the use of alternative fuels like liquefied natural gas (LNG). In order to estimate the effect of these technologies and of legislation on $\mathrm{NO}_{x}$ and $\mathrm{SO}_{2}$ emissions from ships, emission scenarios were developed for the year 2030. These scenarios consider the same development of the world fleet but different developments in legislation and the use of alternative fuels. The basis is a detailed emission inventory for the year 2011 which is built upon AIS (Automatic Identification System) ship positions and a detailed ship characteristics database (Aulinger et al., 2016). The scenarios are implemented as modified emission inventories for the year 2030. The inventories serve as input for the CMAQ chemistry transport model that is set up for the North Sea region. CMAQ calculates transport and transformation of the emitted pollutants and finally yields concentration maps that illustrate the impact of shipping emissions on the air quality in the North Sea region.

\section{Ship emission inventories}

\subsection{Reference emissions}

The basis for the ship fleet and the ship movements on the North Sea is a data set with AIS positions of ships for the entire year 2011 combined with a ship characteristics data base that includes all ships given in the AIS data set. The data are used to calculate the energy demand of individual ships depending on the installed engine and their actual velocity. From this, fuel use as well as $\mathrm{NO}_{x}, \mathrm{SO}_{2}, \mathrm{CO}_{2}, \mathrm{CO}$, hydrocarbon $(\mathrm{HC})$, and particulate matter (PM) emissions are calculated with load-dependent emission factors for the different species. For the first time, load-dependent emission factors resulting from test bed measurements of about 450 different ship engines were used to calculate a ship emission inventory. For the details, the reader is directed to the accompanying paper by Aulinger et al. (2016).

\subsection{Scenario description}

The purpose of scenarios is to describe plausible and possible future developments. Scenarios are often used to describe the boundaries of possible future situations, e.g. a worst case and a best case. In our study we decided to create scenarios that describe the future development of policy and technology regarding exhaust gas emissions from ships in the North Sea area. We adopted the methodology described in Eyring et al. (2005) for our scenarios and distinguish between traffic demand and future technological and legislative developments. However, because we focus on the implementation of a $\mathrm{NO}_{x}$ emission control area in the North Sea, we take only one scenario for the fleet development into account as a basis, as is described in publications from the IMO (Buhaug et al., 2009; Smith et al., 2014) and Det Norske Veritas (Det Norske Veritas, 2012). Taking multiple possible developments of the world trade into account would add too much complexity to the scenarios.

In brief, our fleet development scenario assumes an increase in the number of bigger ships, while the number of smaller ships decreases in the North Sea area. This leads to an increase in ship number by $1.0 \%$ p.a. and an increase in transported cargo of $2.5 \%$ p.a. In addition to this increase in ship number, it is assumed that per year $2.5 \%$ of all ships are replaced by new ones, no matter what size they are. Older ships are replaced first. The main techniques under investigation are liquefied natural gas (LNG) as an alternative fuel for shipping and end-of-the-pipe technologies like scrubbers and selective catalytic reduction (SCR) to reduce sulfur dioxide and nitrogen oxide emissions.

The main drivers of changes in the use of ship fuels and in the amount of emissions to air are on the one hand regulations, and here mainly what is written in MARPOL Annex VI (International Maritime Organization, 2008), and on the other hand the price of different fuels. Therefore, the main scenarios include strict and less strict legislations as one axis and the price of LNG compared to marine gas oil (MGO) or heavy fuel oil (HFO) as the second axis. Some regulations in MARPOL Annex VI (those related to $\mathrm{NO}_{x}$ emissions) are only valid for newly built ships after a certain date, depending on the region where the ECA is located. The earliest date when Tier III $\mathrm{NO}_{x}$ regulations will come into force is $1 \mathrm{Jan}-$ uary 2016. For the North Sea and the Baltic Sea, it is likely that Tier III $\mathrm{NO}_{x}$ regulations will be implemented significantly later than 2016.

Tier III $\mathrm{NO}_{x}$ regulations apply only to new ships. Therefore, some time is needed until a considerable number of 
ECA SCR 21 ECA SCR 16

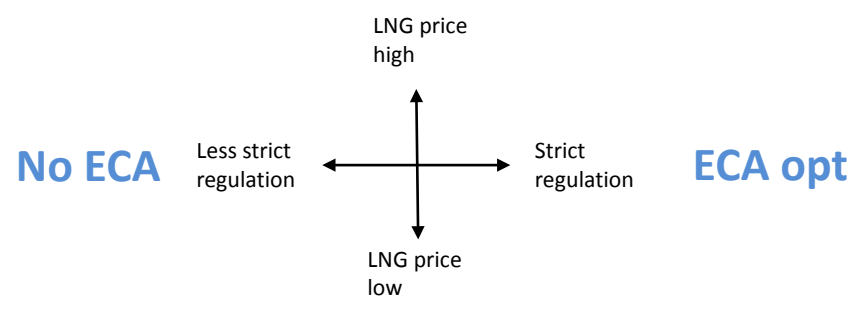

\section{ECA LNG 21 ECA LNG 16}

Figure 1. Scenario identifiers for technical developments and legislation with respect to ship emissions for 2030.

ships in the fleet will have reduced $\mathrm{NO}_{x}$ emissions. Those regulations related to the sulfur content in ship fuels apply to all ships, and should have immediate effects on the total emissions of sulfur oxides. To particularly take into account the long-term effects of new ships following Tier III regulations, the year 2030 is used in the scenarios as the target year. The development of the world fleet until 2030 compared to the reference year 2011 is considered.

These drivers are combined into six scenarios that can be arranged in a coordinate system with legislation on the $x$ axis and LNG price on the $y$ axis (see Fig. 1). Different implementation dates for $\mathrm{NO}_{x}$ Tier III rules (2016 and 2021) are chosen.

The stories behind these scenarios can be described as follows.

\section{- Scenario No ECA}

The global economy suffers from low GDP growth rates, and in order to avoid additional costs for the shipping industry, some regulations will not be implemented (global $\mathrm{SO}_{x}$ limit, $\mathrm{NO}_{x}$ limits in ECAs). This can be considered as the worst case scenario; however, $0.1 \% \mathrm{~S}$ in fuels in ECAs will still be implemented.

\section{- Scenarios ECA SCR 16 and ECA SCR 21}

All regulations currently given in MARPOL Annex VI will be in force. The global sulfur limit of $0.5 \% \mathrm{~S}$ in fuel will be in force by 2020; in ECAs a sulfur limit of $0.1 \%$ $\mathrm{S}$ will be implemented from 2015. $\mathrm{A} \mathrm{NO}_{x}$ emission control area will be implemented in the North and Baltic seas. Two different years, 2016 and 2021, are considered as implementation dates. LNG is expensive and the LNG infrastructure is not built up to provide LNG to many ships. Therefore ship owners will prefer lowsulfur fuels and catalysts (SCR) or exhaust gas recirculation systems (EGR) to comply with the rules. Some will use scrubbers only, if they do not have to follow the Tier III regulations (older ships).

- Scenario ECA LNG 16 and ECA LNG 21

The legislation is the same as in scenarios ECA SCR 16 and ECA SCR 21, but LNG will be the cheaper solution to comply with the rules. In 2030, about 6000 ships in the North Sea will run on LNG. Ships that sail more than $50 \%$ of the time in the North and Baltic seas will preferably use LNG. Some newer ships will also be retrofitted with LNG engines.

\section{- Scenario ECA opt}

This is based on scenario ECA SCR, but it assumes that the strict rules for $\mathrm{NO}_{x}$ emissions for newly built ships will also apply to older ships in 2030. They will then be retrofitted with exhaust gas cleaning systems in order to follow these rules. This is regarded as the best case scenario and illustrates the reduction potential. However, exhaust gas cleaning systems increase the fuel consumption, so the fuel use in this scenario will be higher than in the previous scenarios in which only parts of the ships are equipped with exhaust gas cleaning.

\subsection{Future shipping emissions}

The emission inventories that were constructed as input for the CMAQ model were developed from the ship emission inventory for 2011 which is based on AIS data and ship characteristics data. First, the fleet development was applied. Then, the new emissions were calculated by using modified emission factors for the specific emissions of the ships. All emission factors are given in $\mathrm{g} \mathrm{kWh}^{-1}$ for the different substances under investigation; they have been reduced, depending on the scenario and taking into account the age of the different ships in scenarios ECA SCR and ECA LNG. In particular, in all scenarios it has been taken into account that a fraction of the older ships that do not have to follow any of the Tier rules for $\mathrm{NO}_{x}$ emissions will be taken out of service until 2030 and will be replaced by ships following Tier II. In areas where no AIS data were available (e.g. west of France), shipping emissions as given in the EMEP inventory were used.

The LNG scenarios differ from the SCR scenarios in the following way: $\mathrm{SO}_{2}$ emissions are zero, while they are about $0.38 \mathrm{~g} \mathrm{kWh}^{-1}$ for the SCR case. This a reduction by a factor of 10 compared to the base case and corresponds to a sulfur content of $0.1 \% \mathrm{~S}$, an average fuel consumption of $200 \mathrm{~g} \mathrm{kWh}^{-1}$ and a ratio of $95 \%$ of the total sulfur emitted as $\mathrm{SO}_{2}$. Also, $\mathrm{PM}$ emissions are set to zero in the LNG case. For SCR use, sulfate emissions are again reduced by a factor of 10 according to the sulfur reduction from 1.0 to $0.1 \% \mathrm{~S}$ in the fuel. Other PM emissions are kept constant. $\mathrm{NO}_{x}$ emissions were the same for both, LNG and SCR scenarios. They differ in the implementation date of Tier III rules, only.

The changes in the annual average emissions of $\mathrm{NO}_{x}$ and $\mathrm{SO}_{x}$ in comparison to the reference emissions of 2011 are given for the scenarios in Figs. 2 and 3, respectively. Regional differences in the emission changes are a result of ship types and ship sizes which undergo different temporal devel- 

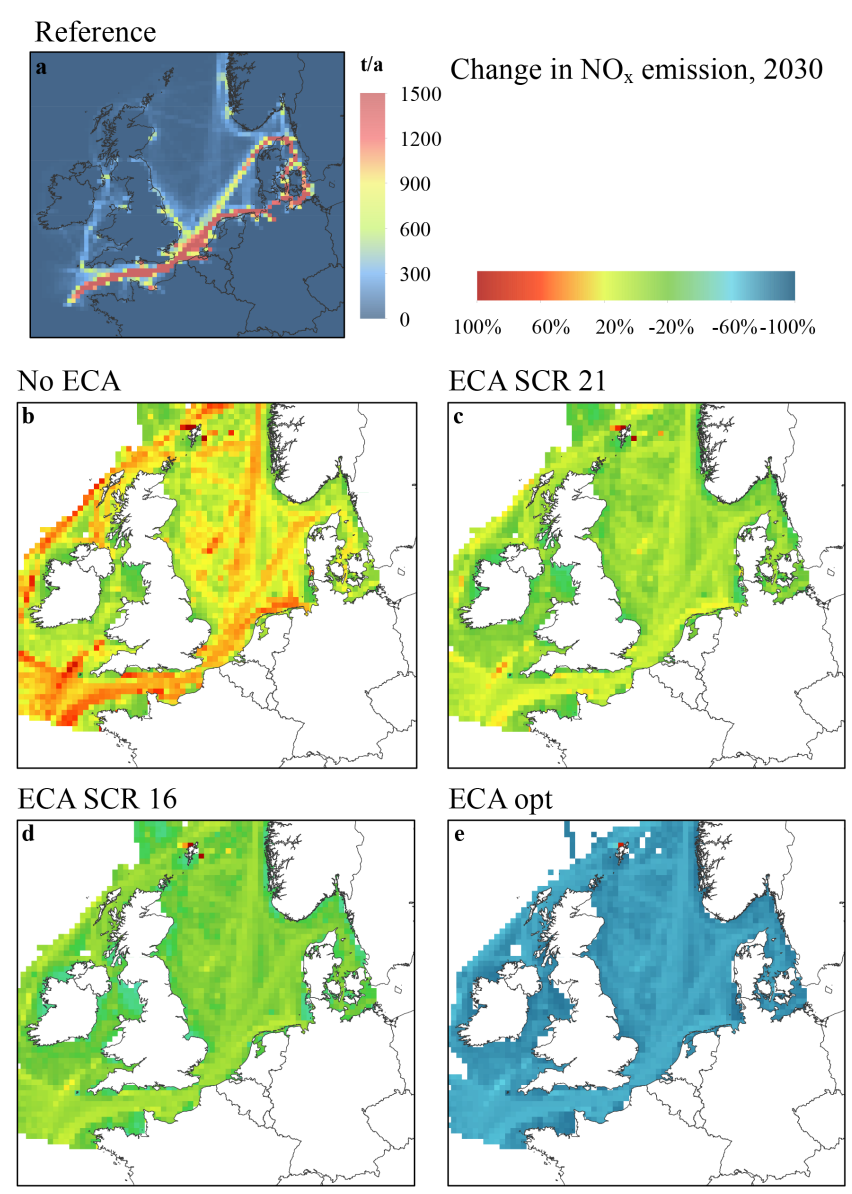

Figure 2. $\mathrm{NO}_{x}$ emissions from ships: (a) annual totals in t per grid cell of $24 \times 24 \mathrm{~km}^{2}$. Emission changes for scenarios (b) No ECA, (c) ECA SCR21, (d) ECA SCR 16, and (e) ECA opt for 2030. No values are shown in grid boxes where the $\mathrm{NO}_{x}$ emissions from ships were below $0.5 \mathrm{t} \mathrm{a}^{-1}$ per grid cell of $24 \times 24 \mathrm{~km}^{2}$.

opments in fleet renewal. This depends on the actual age of the ships given in the ship characteristics database.

\section{Chemistry transport modelling}

\subsection{CMAQ}

The CMAQ model (Byun and Ching, 1999; Byun and Schere, 2006) was used in its version 4.7.1 with the CB05 chemistry mechanism. Compared to its previous version, the model update includes several new features (Foley et al., 2010); among them are gas-phase chlorine chemistry, improved secondary organic aerosol (SOA) formation (Edney et al., 2007), and an updated representation of sea salt that considers reactions with nitric acid and the formation of coarse-mode nitrate (Kelly et al., 2010) in the so-called AE5 aerosol mechanism. The model was run for an entire year with a spinup time of 2 weeks. Standard profiles for the most

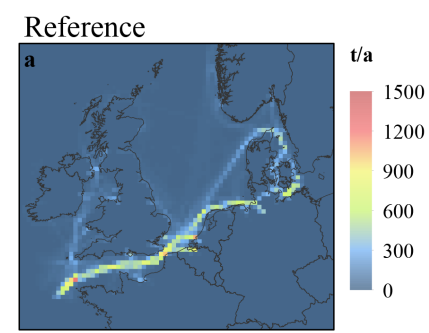

Change in $\mathrm{SO}_{2}$ emission, 2030

ECA SCR 16
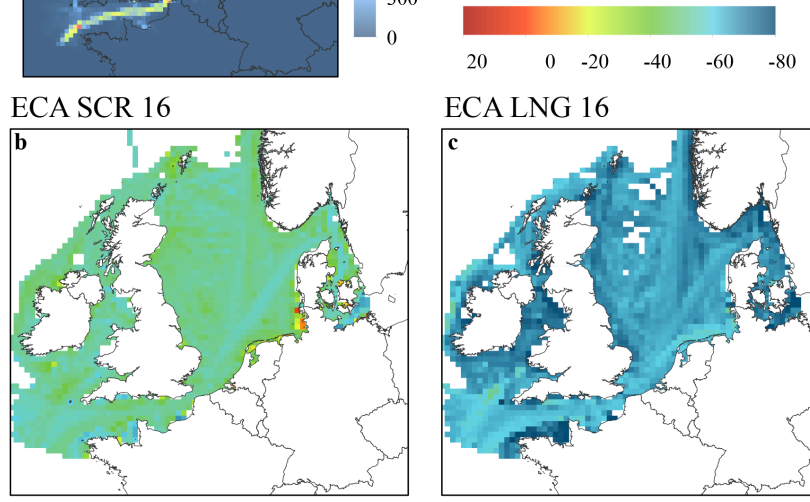

ECA LNG 16

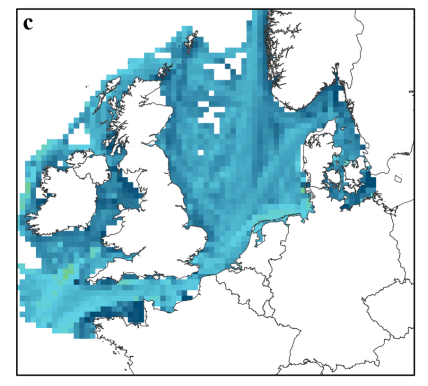

Figure 3. $\mathrm{SO}_{2}$ emissions from ships: (a) annual totals in t per grid cell of $24 \times 24 \mathrm{~km}^{2}$. Emission changes for scenarios (b) ECA SCR 16 and (c) ECA LNG 16 for 2030. No values are shown in grid boxes where the $\mathrm{SO}_{2}$ emissions from ships were below $0.5 \mathrm{ta}^{-1}$ per grid cell of $24 \times 24 \mathrm{~km}^{2}$.

important atmospheric pollutants were used as initial conditions. However, their effect on the simulated atmospheric concentrations of the substances in focus in this paper is negligible after the spinup.

The model was set up on a $72 \times 72 \mathrm{~km}^{2}$ grid for all of Europe and subsequently on a nested $24 \times 24 \mathrm{~km}^{2}$ grid for central Europe; see Fig. 4. The vertical model extent contains 30 layers up to $100 \mathrm{hPa}$ in a sigma hybrid pressure coordinate system. Twenty of these layers are below approx. $2 \mathrm{~km}$; the lowest layer extends to ca. $36 \mathrm{~m}$ above ground. The evaluation area was restricted to the greater North Sea region and some neighbouring sections of the north-eastern Atlantic, covering approximately half of the central European domain (see the red box in Fig. 4).

\subsection{COSMO-CLM}

The meteorological fields that drive the chemistry transport model were simulated with the COSMO-CLM mesoscale meteorological model (version 4.8) for the year 2008 (Geyer, 2014) using NCEP forcing data (Kalnay et al., 1996). This year was chosen because it does not contain very unusual meteorological conditions in Europe and can therefore be used to represent typical weather conditions in Europe. The same meteorological fields were used for the scenario runs; that is, projected changes due to climate change were not considered in order to avoid a mixture of effects, from emissions and meteorological data, in the resulting concentrations of air pollutants. 

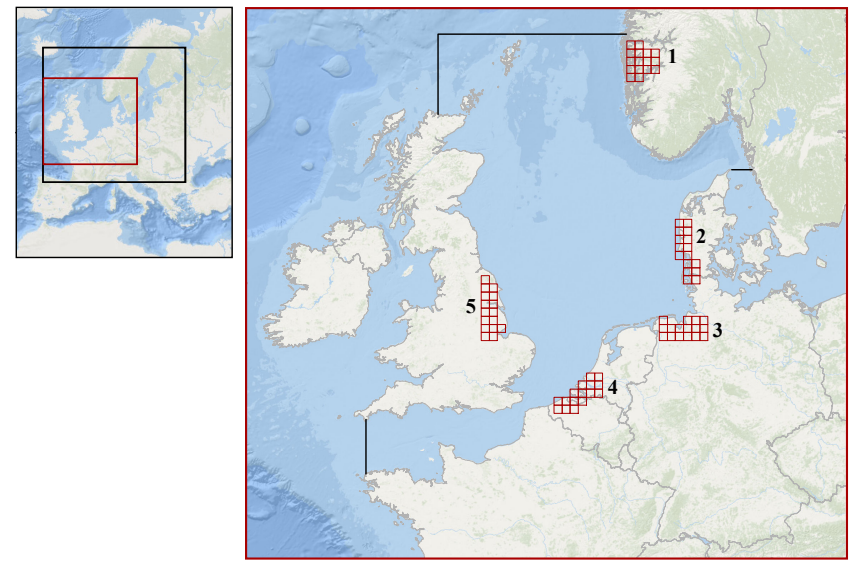

Figure 4. Left: modelling domains, outer domain with $72 \times 72 \mathrm{~km}^{2}$ resolution (outer black line), inner domain with $24 \times 24 \mathrm{~km}^{2}$ resolution (inner black line), and the evaluation area (red line). Right: evaluation area including the greater North Sea region illustrating also the five regions (namely 1 to 5) for which time series of pollutant concentrations have been derived from CMAQ modelling results.

COSMO-CLM is the climate version of the COSMO regional-scale meteorological community model (Rockel et al., 2008), originally developed by the Deutscher Wetterdienst (DWD) (Steppeler et al., 2003; Schättler et al., 2008). It has been run on a $0.22^{\circ} \times 0.22^{\circ}$ grid using 40 vertical layers up to $20 \mathrm{hPa}$ for the whole of Europe. COSMOCLM uses the TERRA-ML land surface model (Schrodin and Heise, 2001), a turbulent kinetic energy (TKE) closure scheme for the planetary boundary layer (Doms and Baldauf, 2002; Doms et al., 2011), cloud microphysics after Seifert and Beheng (2001, 2006), the Tiedtke scheme (Tiedtke, 1989) for cumulus clouds, and a long-wave radiation scheme following Ritter and Geleyn (1992). The meteorological fields were afterwards processed to match the CMAQ grid. As far as possible, CMAQ uses the information that is provided by the meteorological input fields to calculate transport, transformation and loss of all gas-phase and particulate species. The impact of the meteorological fields on the output of the chemistry transport model was investigated in detail in the articles by Matthias et al. (2009) and Bieser et al. (2011a).

\subsection{Boundary conditions}

Chemical boundary conditions for the outer model domain were taken from monthly means of the TM5 global chemistry transport model system (Huijnen et al., 2010) and were provided by the Dutch Royal Meteorological Institute (KNMI). The model results have been interpolated in time and space to provide daily boundary conditions for the $72 \times 72 \mathrm{~km}^{2}$ CMAQ grid for Europe. Boundary conditions for the nested $24 \times 24 \mathrm{~km}^{2}$ grid were calculated on an hourly basis from the outer coarse grid. They were kept the same for all scenarios in order to restrict the analysis of the effects of emission changes on shipping in north-western Europe.

\subsection{Land-based emissions}

The model runs were performed with full emissions from all relevant sources in the model domain. Land-based emissions in hourly temporal resolution were produced with SMOKE EU (Bieser et al., 2011a) for the year 2011. They are based on officially reported EMEP emissions which are distributed in time and space using appropriate surrogates like population density, street maps or land use. Point sources were considered as far as information from the European point source emission register was available. The vertical distribution of the emissions was calculated online with the SMOKE model; the results are given by Bieser et al. (2011b). The land-based emissions were kept constant for all scenario model runs. Therefore the impact of reduced land-based emissions, which can be expected for Europe in the year 2030, was not considered here. This was done to keep the analysis clear and to discuss only the effects of shipping instead of mixing them up with reductions of land-based sources.

\section{Impact of shipping on concentrations of pollutants}

\subsection{Situation today}

The results for today's air pollution due to shipping serve as a reference case for this study. They are discussed in detail in the accompanying paper by Aulinger et al. (2016). In brief, it can be said that ships contribute significant amounts to the concentrations of $\mathrm{NO}_{2}$, particle-bound nitrate $\left(\mathrm{NO}_{3}^{-}(\mathrm{p})\right)$ and particle-bound sulfate $\left(\mathrm{SO}_{4}^{2-}(\mathrm{p})\right)$. In summer, ozone is enhanced, too. High contributions from shipping to the $\mathrm{NO}_{2}$ and $\mathrm{SO}_{2}$ concentrations are restricted to the open sea and the coastal areas in the southern North Sea and in Denmark (see the reference case in Figs. 5 and A1). Nitrate and sulfate aerosol particles as well as ozone are secondary pollutants. They are transported far more inland, but their relative contribution to concentrations at the coast is lower compared to $\mathrm{NO}_{2}$ and $\mathrm{SO}_{2}$.

There are large differences between summer and winter. Partly, they can be ascribed to seasonal differences in the emissions, with higher shipping emissions in summer. Most of the differences in the concentrations are caused by atmospheric chemistry. As a photochemical pollutant, ozone is only increased during the summer months. The situation is similar for sulfate and nitrate aerosol. Both are formed via oxidation pathways that include the photochemically formed $\mathrm{OH}$ radical. Therefore, the conversion rate of $\mathrm{SO}_{2}$ into $\mathrm{SO}_{4}^{2-}(\mathrm{p})$ and of $\mathrm{NO}_{2}$ into $\mathrm{NO}_{3}^{-}(\mathrm{p})$ in summer is higher than in winter. This leads to higher contributions of shipping emissions to the concentrations of these aerosol components 

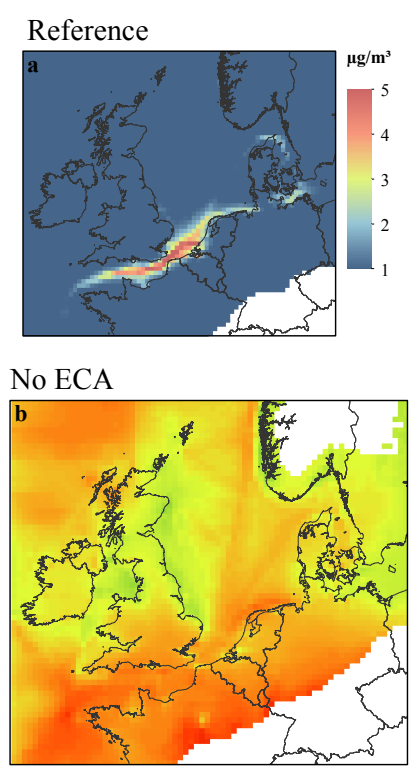

ECA SCR 16

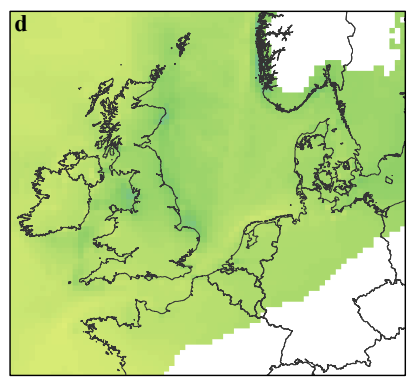

ECA SCR 21

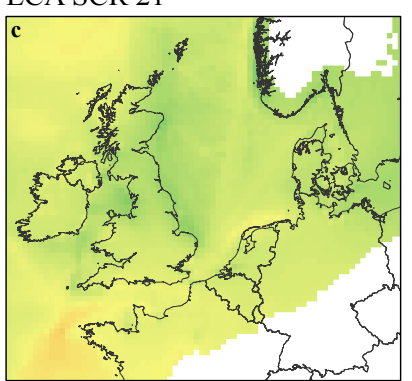

ECA opt

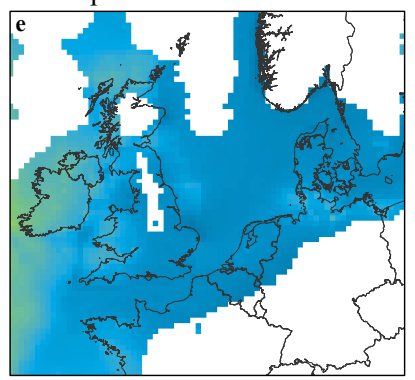

Figure 5. Contribution of shipping to the total $\mathrm{NO}_{2}$ concentrations in summer (JJA) (a) today (Reference) and change in scenarios (b) No ECA, (c) ECA SCR 21, (d) ECA SCR 16, and (e) ECA opt. No values are shown in grid boxes where the contribution from shipping to the $\mathrm{NO}_{2}$ concentrations in either the reference or the scenario case was below $0.05 \mu^{-3} \mathrm{~m}^{-3}$.

in summer. On the other hand, total nitrate aerosol concentrations are much lower in summer compared to winter, because the gas-to-particle partitioning between $\mathrm{HNO}_{3}$ and $\mathrm{NO}_{3}^{-}(\mathrm{p})$ is temperature dependent, with higher particulate nitrate concentrations at low temperatures.

\subsection{Scenarios for the North Sea in $\mathbf{2 0 3 0}$}

To derive the contribution of ships to the selected pollutant concentrations, two model runs, one including and one excluding shipping emissions, were performed. The difference is regarded as the contribution of ships to the individual pollutant. For the scenarios, the difference between two model runs with different shipping emissions is regarded as the change in the contribution of ships in the respective scenario. The evaluation is restricted to concentrations in the lowest model level, because they are most relevant for the population.

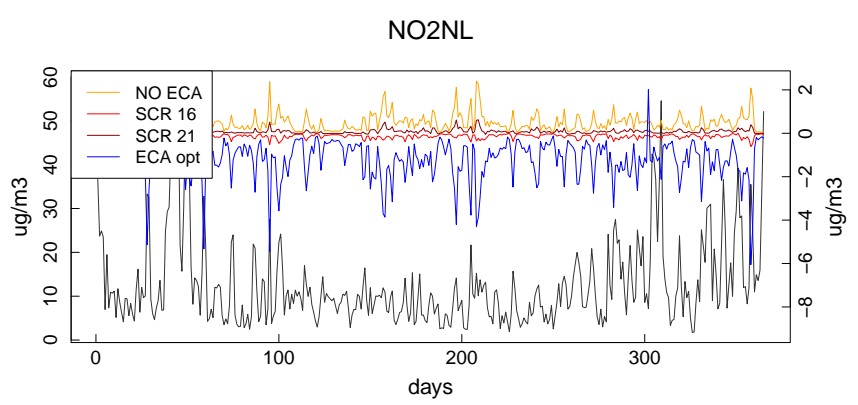

Figure 6. Time series of daily average $\mathrm{NO}_{2}$ concentrations in $\mu \mathrm{g} \mathrm{m}^{-3}$ (black, left $y$ axes) and change in the contribution of shipping to the $\mathrm{NO}_{2}$ concentrations in the coastal areas of Belgium and the Netherlands (region 4) for all scenarios (coloured, right $y$ axes).

We mainly discuss the consequences of changes in the $\mathrm{NO}_{x}$ emissions from ships because here we see the main differences between the scenarios (Fig. 2). Additionally, the strict rules for $\mathrm{SO}_{2}$ came into force in the North Sea ECA on 1 January 2015, and there are only small differences between the scenarios with respect to $\mathrm{SO}_{2}$ emissions in the North Sea (Fig. 3). This will be further discussed in Sect. 4.2.4.

$\mathrm{NO}_{x}$ emissions from ships have an impact on the $\mathrm{NO}_{2}$ concentrations, on nitrate aerosol and on ozone. It can be expected that $\mathrm{NO}_{2}$ concentrations will increase due to ship emissions. The impact of $\mathrm{NO}_{x}$ emissions from ships on ozone will be different between winter and summer. While in summer increased $\mathrm{NO}_{x}$ emissions will lead to increased ozone under most weather conditions and in most regions, this will have almost no effect in winter.

In the following, maps illustrating changes in the contribution of shipping to $\mathrm{NO}_{2}$, nitrate aerosol and ozone concentrations in 2030 will be shown for the scenarios No ECA, ECA SCR 16 (Tier III in 2016), ECA SCR 21 (Tier III in 2021) and ECA opt. The colour-coded relative changes refer to the impact of the shipping emissions on the concentrations of selected pollutants. The latter is given in reference maps which are results of the reference model run considering shipping emissions from 2011. The changes in the other scenarios will be illustrated in time series for different North Sea coastal regions (see Fig. 4), each of them comprising about $9200 \mathrm{~km}^{2}$. These time series nicely show the highly variable impact of shipping emissions, which depends to a large extent on the weather conditions and the concentrations of pollutants from other sources.

\subsubsection{Nitrogen dioxide}

Scenario No ECA reflects a steady increase in shipping activity disregarding the implementation of stricter rules for $\mathrm{NO}_{x}$ emissions. This will lead to an increase in the contribution of shipping to the average $\mathrm{NO}_{2}$ concentrations by more than $30 \%$ in large areas of the North Sea region (Fig. 5b). The largest increase can be seen in the English Channel and the 
south-western North Sea, while Norway and Sweden exhibit lower increase rates of around $20 \%$.

Figure 5 c displays scenario ECA SCR 21 in which the Tier III rules for new ships come into force in 2021. This means that in 2030 a large part of the fleet will still follow the less strict Tier I and Tier II regulations. Very few ships older than 30 years will not have to comply with any of the $\mathrm{NO}_{x}$ regulations. As a consequence, the contribution of ships to average $\mathrm{NO}_{2}$ concentrations will be higher than in the case with Tier III regulations from 2016 onwards (Fig. 5d). In large parts of the North Sea the contribution of shipping to $\mathrm{NO}_{2}$ concentrations will be higher than today.

Scenario ECA SCR 16 on average still shows a moderate increase in the $\mathrm{NO}_{2}$ concentrations caused by ships compared to the situation today (Fig. 5d). While in the English Channel and the southern North Sea the concentrations decrease by a few percent only, they decrease by more than $10 \%$ in the north-western parts of the North Sea and in particular at the British, Norwegian and Swedish coasts. This is caused by the fact that the traffic to the main North Sea ports in Rotterdam, Hamburg, and Antwerp will still increase and ships will become bigger, resulting in a rather small concentration decrease in the English Channel. Today, smaller and older ships travel to the smaller harbours in the North Sea area. However, many of them will be replaced after 2016, which means that a large fraction of those ships will comply with Tier III. This will lead to a reduction of the contribution of shipping emissions to $\mathrm{NO}_{2}$ concentrations in the central and northern parts of the North Sea.

The contribution of shipping to $\mathrm{NO}_{2}$ concentrations will be drastically reduced in the case of scenario ECA opt when all ships comply with Tier III rules for $\mathrm{NO}_{x}$ emissions (Fig. 5e). The simulations show a reduction of approximately $80 \%$ all over the North Sea region compared to today.

All reductions in the contribution of shipping to $\mathrm{NO}_{2}$ concentrations have a similar magnitude and regional distribution in winter and summer. On average the impact of shipping is slightly higher in winter compared to summer with a larger increase in scenarios No ECA and ECA SCR 21 and a smaller decrease in scenarios ECA SCR 16 and ECA opt. All maps for the winter case can be seen in the appendix (Fig. A3).

Figure 6 shows a time series of the contribution of shipping to the daily average $\mathrm{NO}_{2}$ concentrations at the coasts of Belgium and the Netherlands (see Fig. 4 for the region). Of the scenarios for 2030, scenario ECA SCR 16 shows a slight decrease in the contribution of shipping to the $\mathrm{NO}_{2}$ concentrations compared to today. If Tier III will be implemented in 2021 (scenario ECA SCR 21) or not at all until 2030 (scenario No ECA), the contribution of shipping to the $\mathrm{NO}_{2}$ concentration will be higher than today. Large reductions of $\mathrm{NO}_{2}$ from shipping, on some days more than $4 \mu \mathrm{g} \mathrm{m}^{-3}$, are only achieved when all ships and not only new buildings follow the Tier III regulations. Time series for the other regions are included in the Appendix (Fig. A6).

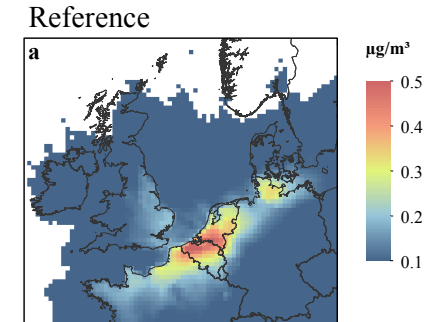

Change in $\mathrm{NO}_{3}$ concentration from ships, summer 2030

No ECA



ECA SCR 16

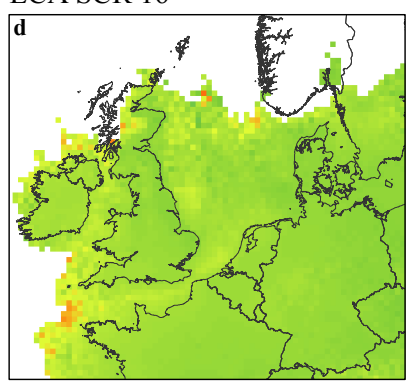

\section{ECA SCR 21}

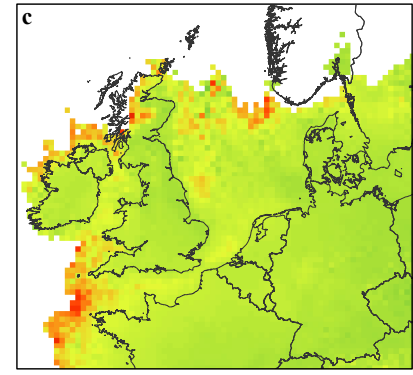

ECA opt

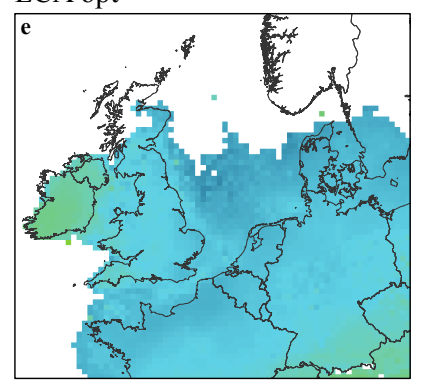

Figure 7. Contribution of shipping to the total $\mathrm{NO}_{3}^{-}$concentrations in summer (JJA) (a) today (Reference) and change in scenarios (b) No ECA, (c) ECA SCR 21, (d) ECA SCR 16, and (e) ECA opt. No values are shown in grid boxes where the contribution from shipping to the $\mathrm{NO}_{3}$ concentrations in either the reference or scenario case was below $0.005 \mu \mathrm{g} \mathrm{m}^{-3}$.

\subsubsection{Nitrate aerosol}

Nitrate aerosol $\left(\mathrm{NO}_{3}^{-}(\mathrm{p})\right)$ is formed in the atmosphere as a consequence of the oxidation of $\mathrm{NO}_{2}$. The amount of aerosol particles formed highly depends on the presence of other pollutants, in particular on the availability of ammonia $\left(\mathrm{NH}_{3}\right)$. Ammonia mainly stems from agricultural activities. The regions with the highest ammonia emissions are western France, the Benelux countries, western Germany and Denmark. Particulate ammonium nitrate preferentially exists in winter, at low temperatures. At higher temperatures ammonium nitrate particles decompose into gaseous ammonia and nitric acid. Therefore, nitrate aerosol concentrations all over Europe are much lower in summer compared to winter. On the other hand, oxidation of $\mathrm{NO}_{2}$ is much more effective in summer, leading to a higher contribution of shipping to nitrate aerosol compared to winter. 

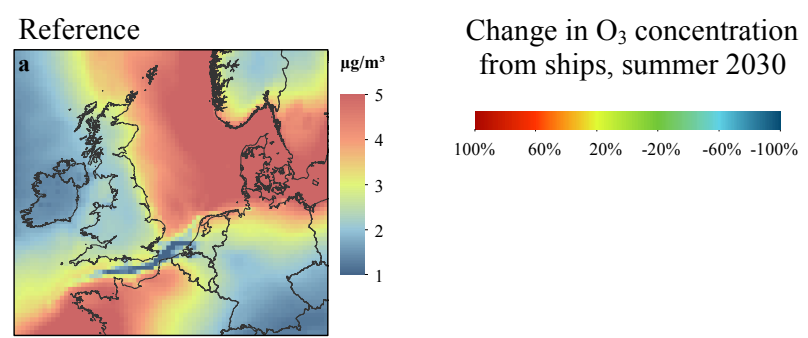

No ECA

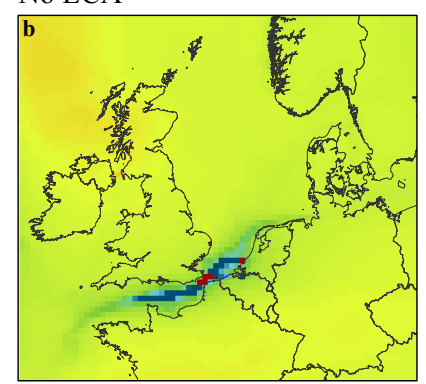

ECA SCR 16

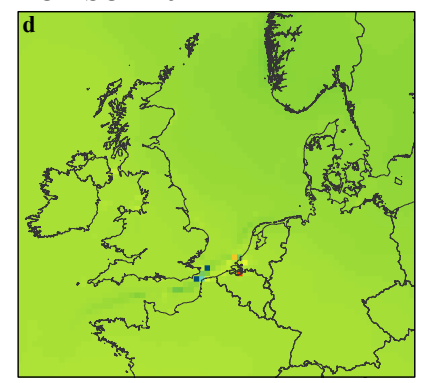

ECA SCR 21

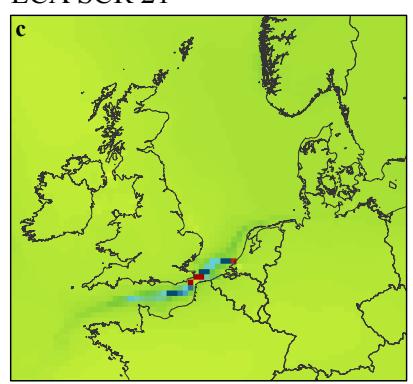

ECA opt

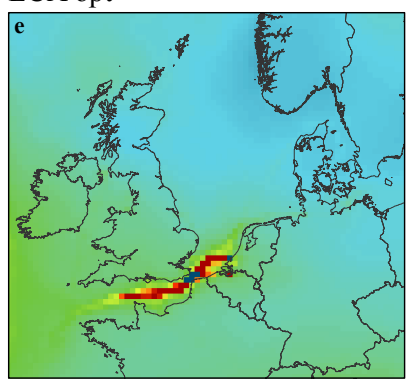

Figure 8. Contribution of shipping to the mean $\mathrm{O}_{3}$ concentrations in summer (JJA) (a) today (Reference) and change in scenarios (b) No ECA, (c) ECA SCR 21, (d) ECA SCR 16, and (e) ECA opt.

In summer, the emission scenarios show very similar results for nitrate aerosol and for $\mathrm{NO}_{2}$ (see Fig. 7). In scenario No ECA the contribution of shipping to nitrate aerosol concentrations increases by more than $30 \%$ over sea and by $25 \%$ or more in large areas of central Europe and in southern Scandinavia (Fig. 7b). In scenario ECA SCR 21 (Fig. 7c) large areas of the North Sea, and in particular northern France, show an increase in nitrate aerosol from shipping, while in other areas the situation will remain unchanged. Scenario ECA SCR 16 (Fig. 7d) shows a decrease in the contribution of shipping to nitrate aerosol concentrations by $7-$ $10 \%$ in the north-eastern part of the North Sea, while in the south-western part a small increase by $5-10 \%$ can be observed. Again, in scenario ECA opt the contribution of shipping to nitrate aerosol will be reduced by $60-80 \%$.

In winter, nitrate aerosol concentrations are only marginally affected by shipping emissions. For this reason the results of the scenario runs do not show reliable patterns of changes in $\mathrm{NO}_{3}^{-}(\mathrm{p})$ concentrations caused by changing shipping emissions when given as relative changes. Therefore, they are not shown.

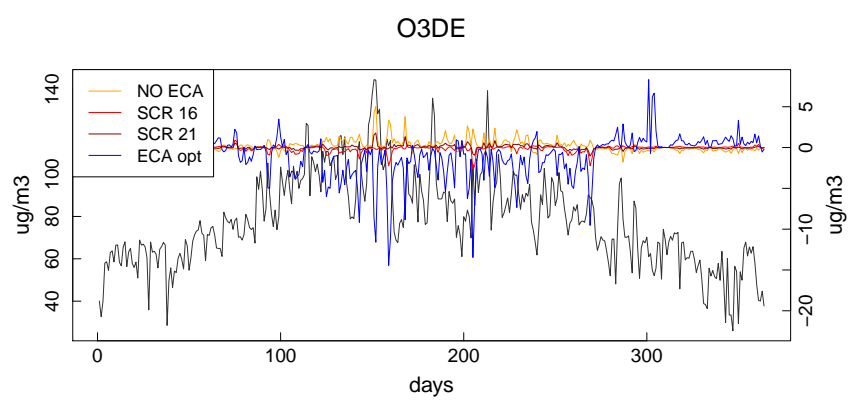

Figure 9. Time series of daily average ozone concentrations in $\mu \mathrm{g} \mathrm{m}^{-3}$ (black, left $y$ axes) and change in the contribution of shipping to the ozone concentrations in the coastal areas of Germany (region 3) for all scenarios (right $y$ axes).

\subsubsection{Ozone}

$\mathrm{NO}_{x}$ emissions from ships have a strong influence on the atmospheric ozone concentrations. Ozone is formed out of $\mathrm{NO}_{2}$ and atmospheric oxygen in the presence of sunlight. Volatile organic compounds (VOCs) help to transform emitted $\mathrm{NO}$ into $\mathrm{NO}_{2}$, thereby enhancing the ozone formation significantly. On the other hand, NO destroys ozone, leading to low ozone concentrations during night-time when no photolysis of $\mathrm{NO}_{2}$ takes place. This leads to a strong diurnal cycle of the ozone concentration and a large difference between winter and summer levels, with much higher ozone concentrations in the summer. Furthermore, increased $\mathrm{NO}_{x}$ emissions may cause additional ozone formation in the presence of sufficiently high VOC concentrations. If the VOC levels are comparably low, more $\mathrm{NO}_{x}$ causes ozone destruction.

Here, we look at the impact of shipping emissions on the daily mean ozone values. Figure 8 shows maps of the distribution of changes in the contribution of ships to mean ozone concentration for the different scenarios. Fig. 8a shows that shipping causes about $7 \mu \mathrm{g} \mathrm{m}^{-3}$ additional ozone (summer average value) in large parts of the North Sea and in Denmark. On the other hand, there is only a small increase in ozone in the English Channel, where $\mathrm{NO}_{x}$ concentrations are high. The effect of ozone destruction by additional $\mathrm{NO}_{x}$ emissions under low VOC conditions can be clearly seen in scenario No ECA (Fig. 8b). Reductions in ozone concentrations caused by shipping emissions, by partly more than $80 \%$, are clearly noticeable in the English Channel, the south-western North Sea and the surrounding coastline. On the other hand, the shipping contribution to increased ozone concentrations will be enhanced by more than $20 \%$ far from the main shipping areas in central Europe, Ireland and the northern UK.

Scenario ECA SCR 21 (Fig. 8c) contains higher $\mathrm{NO}_{x}$ emissions, leading to decreased ozone in the English Channel and higher values in central Europe, France, Ireland and the UK. Scenario ECA SCR 16 (Fig. 8d) shows a lower ship- 
Table 1. Number of days with $8 \mathrm{~h}$ maximum ozone concentrations greater than $120 \mathrm{\mu g} \mathrm{m}^{-3}$ in 2030 in selected regions around the North Sea for scenarios No ECA, ECA SCR 16, ECA SCR 21, and ECA opt.

\begin{tabular}{lccccc}
\hline & 1 & 2 & 3 & 4 & 5 \\
\hline 2011 & 9 & 19 & 27 & 46 & 29 \\
No ECA & 9 & 20 & 29 & 46 & 29 \\
ECA SCR 16 & 8 & 18 & 26 & 46 & 29 \\
ECA SCR 21 & 8 & 18 & 27 & 46 & 29 \\
ECA opt & 6 & 12 & 16 & 45 & 22 \\
\hline
\end{tabular}

ping contribution to ozone concentrations in the north-east of the North Sea region and an almost unchanged situation in the south-west. In the case of ECA opt, ozone caused by shipping emissions is significantly reduced by $40-60 \%$ all over the modelling domain, except for the English Channel, where a significant increase is found.

Figure 9 displays a time series of the daily average ozone concentrations in northern Germany. It can be seen that the ozone values would be lower in summer, on some days by more than $10 \mu \mathrm{g} \mathrm{m}^{-3}$, if ships emitted as little $\mathrm{NO}_{x}$ as in the ECA opt scenario. On the other hand, they would be slightly higher in winter.

An analysis of the different regions reveals that the days with concentrations higher than $120 \mu \mathrm{g} \mathrm{m}^{-3}$ (a value recommended by the World Health Organization, WHO) would decrease significantly by $50 \%$ or more without shipping emissions in all regions except the Netherlands (see Table 1). The scenarios for 2030 do not show big differences in the number of days with concentrations above $120 \mu \mathrm{g} \mathrm{m}^{-3}$. While small increases in the number of days can be expected if Tier III rules were not implemented (scenario No ECA), the only case with a strong decrease in exceedance days is scenario ECA opt.

\subsubsection{Sulfur dioxide and sulfate aerosol}

Sulfur dioxide $\left(\mathrm{SO}_{2}\right)$ emissions from ships are directly related to the sulfur content of ship fuels. In the scenarios for 2030 all ships will follow the same rules for sulfur, which allow $0.1 \% \mathrm{~S}$ in the fuel in the North and Baltic Sea ECA and $0.5 \%$ outside of it. Therefore, the scenarios do not differ much in terms of sulfur emissions. The main difference is between the ECA SCR and ECA LNG scenarios, because LNG does not contain any sulfur at all, which makes the sulfur emissions from these ships even lower than for all other ships that comply with the $0.1 \% \mathrm{~S}$ rule inside the North Sea area.

In Fig. 10, changes in the contribution from shipping to the $\mathrm{SO}_{2}$ and $\mathrm{SO}_{4}$ concentrations for scenarios ECA SCR 16 and ECA LNG 16 are shown for summer. In the ECA LNG 16 scenario, sulfur dioxide and sulfate aerosol concentrations are even further reduced than in the ECA SCR 16 scenario.

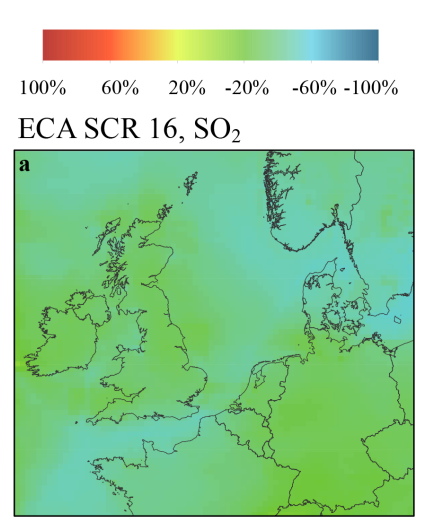

Change in $\mathrm{SO}_{2}$ and $\mathrm{SO}_{4}$ concentration from ships, summer 2030
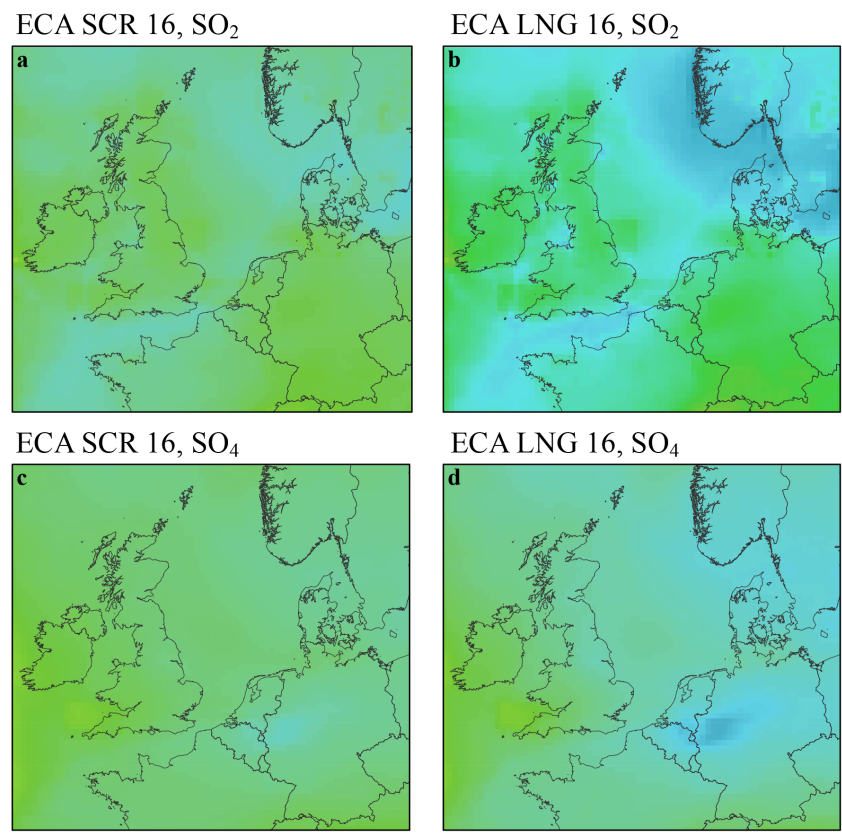

ECA LNG 16, $\mathrm{SO}_{4}$

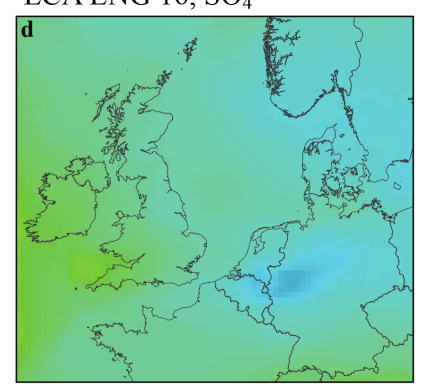

Figure 10. Change in the contribution of shipping to the total (a and b) $\mathrm{SO}_{2}$ and (c and d) $\mathrm{SO}_{4}$ concentrations in summer (JJA) for scenarios ECA SCR 16 (left) and ECA LNG 16 (right) in relation to the reference case. See Figures A1 and A2 for the reference concentrations.

The reductions are between 40 and $60 \%$ for the SCR case and between 60 and $80 \%$ for the LNG case. The reductions are slightly higher for $\mathrm{SO}_{2}$ compared to sulfate; however, the reductions for sulfate are more widespread than those for $\mathrm{SO}_{2}$. The results for the other scenarios are very close to those in Fig. 10, which is why they are not shown here. More maps are included in the Appendix (Figs. A1, A2, A4, and A5).

\subsection{5 $\quad \mathbf{P M}_{2.5}$}

Particulate matter with a diameter less than $2.5 \mu \mathrm{m}\left(\mathrm{PM}_{2.5}\right)$ originating from shipping emissions is mainly formed through a conversion of gaseous $\mathrm{SO}_{2}$ and $\mathrm{NO}_{2}$ into particulate nitrate $\left(\mathrm{NO}_{3}^{-}(\mathrm{p})\right)$ and sulfate $\left(\mathrm{SO}_{4}^{2-}(\mathrm{p})\right)$. The amount of these secondary aerosol components depends critically on the level of $\mathrm{NH}_{3}$ emissions, which are a prerequisite for the formation of ammonium sulfate and ammonium nitrate in the atmosphere. The area where the highest contribution of shipping to the $\mathrm{PM}_{2.5}$ concentrations is noticeable is south-east of the main shipping lanes, in north-western France, Belgium, the Netherlands and northern Germany. These are areas with high ammonia emissions from agricultural activities. 


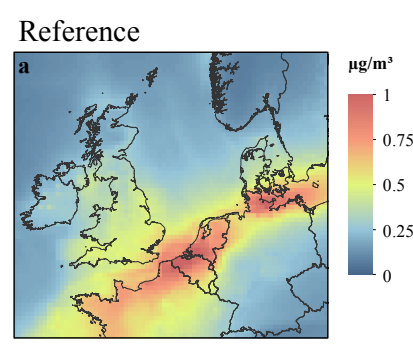

Change in $\mathrm{PM}_{2.5}$ concentration from ships, summer 2030

No ECA

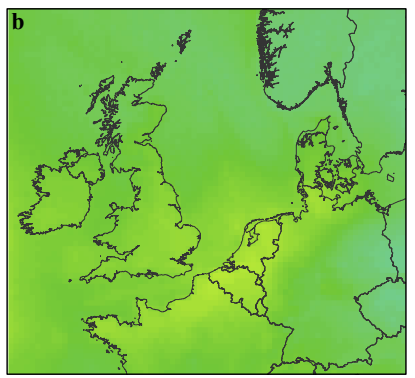

ECA SCR 16

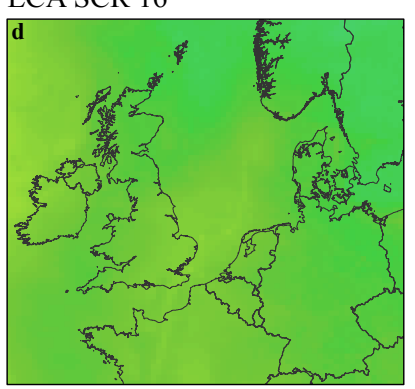

ECA SCR 21

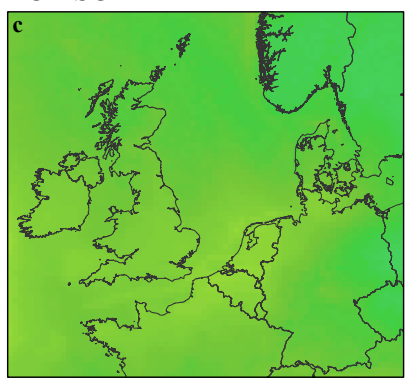

ECA opt

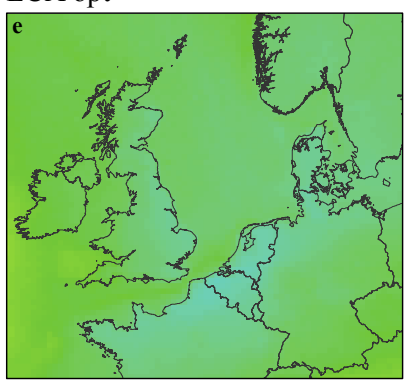

Figure 11. Contribution of shipping to the total $\mathrm{PM}_{2.5}$ concentrations in summer (JJA) (a) today (Reference) and change in the scenarios (b) No ECA, (c) ECA SCR 21, (d) ECA SCR 16, and (e) ECA opt.

Reductions in the contribution of shipping to $\mathrm{PM}_{2.5}$ are visible in all scenarios (see Fig. 11). This is caused by the significant effect the sulfur reductions in the ship fuel have on sulfate aerosol concentrations. In scenario ECA opt the $\mathrm{PM}_{2.5}$ reduction is the largest. Here, nitrate aerosol is also significantly reduced.

The time series for $\mathrm{PM}_{2.5}$ concentrations and the respective reductions in the different scenarios can be seen for northern Germany in Fig. 12. All scenarios except for No ECA show reductions in $\mathrm{PM}_{2.5}$ on almost all days. Again, the largest reductions can be seen for ECA opt. There is no clear seasonal trend for the reductions, although total $\mathrm{PM}_{2.5}$ is higher in winter compared to summer.

\section{Conclusions}

This paper investigates the effects of different future developments of shipping emissions in the North Sea area on air quality in the North Sea region. The main differences be-

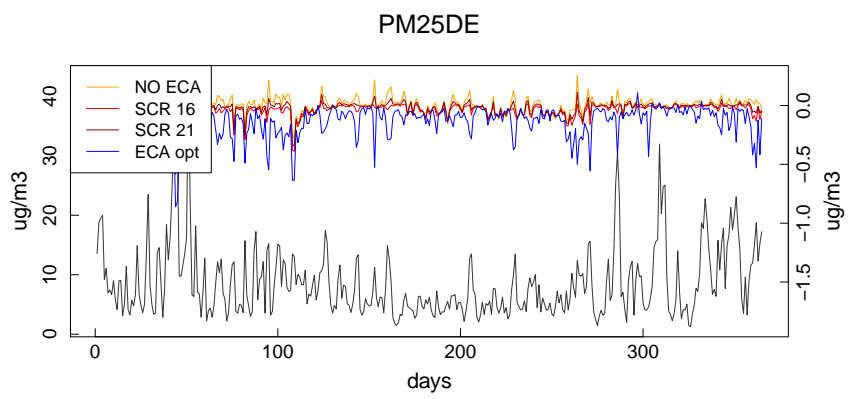

Figure 12. Time series of daily average $\mathrm{PM}_{2.5}$ concentrations in $\mu \mathrm{g} \mathrm{m}^{-3}$ (black, left $y$ axis) and change in the contribution of shipping to the $\mathrm{PM}_{2.5}$ concentrations in the coastal areas of Germany (region 3) for the main scenarios (coloured, right $y$ axis).

tween the scenarios for 2030 concern nitrogen oxide emissions. They could be significantly lowered by using exhaust gas cleaning techniques or alternative fuels like LNG. Additionally, international regulations for a mandatory reduction of nitrogen oxide emissions in the North and Baltic Sea areas are under debate in the International Maritime Organization. To avoid misinterpretations of the results, land-based emissions and meteorological conditions were the same in the scenario runs and in the base case.

It was found that the expected increase in ship traffic in the North Sea will lead to enhanced levels of $\mathrm{NO}_{2}$, nitrate aerosol and ozone in large areas of north-western France, Belgium, the Netherlands, northern Germany and Denmark if no emission reduction measures are taken. For secondary pollutants like ozone and aerosols, this effect is more pronounced in summer compared to winter. In winter, shipping does not contribute much to elevated levels of aerosol concentrations.

The effect of emission reduction measures depends on the year of implementation. If already in 2016 new ships needed to follow the new Tier III rules for new buildings, the concentrations of $\mathrm{NO}_{2}$, nitrate aerosol and ozone in 2030 would be on the same level as today. This means that the emission reductions of the new ships are compensated for by increased ship traffic. If it took another 5 years until Tier III regulations were in place, the concentrations of $\mathrm{NO}_{2}$, nitrate aerosol and ozone which are caused by ship traffic would be higher in 2030 compared to today. The difference from the implementation of the Tier III rules in 2016 would be about $10-15 \%$. Significant reductions can only be achieved if all ships, not only new buildings, follow strict $\mathrm{NO}_{x}$ emission limitations.

The situation is different for sulfur dioxide, sulfate aerosol particles and also for $\mathrm{PM}_{2.5}$. Regulations on lower sulfur levels in ship fuels were implemented on 1 January 2015 for the North Sea and will be in place for all seas in 2020 (or at the latest in 2025). This will significantly reduce the impact of shipping on $\mathrm{SO}_{2}$ and sulfate aerosol concentrations. As a consequence of lower sulfate aerosol concentrations, $\mathrm{PM}_{2.5}$ concentrations will also be reduced. The use of LNG as an 
alternative fuel would further reduce sulfur emissions and therefore also $\mathrm{SO}_{2}$ and $\mathrm{PM}_{2.5}$ concentrations.

Our model study shows that all effects of shipping emissions on air quality differ largely by region and season, depending on the pollutant in focus. Gaseous primary pollutants like $\mathrm{NO}_{2}$ and $\mathrm{SO}_{2}$ have a short lifetime. Consequently, their effects can mainly be seen close to the shipping lanes. Aerosols which are formed through oxidation in the atmosphere can be transported over large distances. Contributions of shipping to nitrate, sulfate and $\mathrm{PM}_{2.5}$ concentrations can be seen far inland. For ozone, future emission reductions of $\mathrm{NO}_{x}$ could even lead to enhanced concentrations in regions that already today have high $\mathrm{NO}_{x}$ and low VOC concentrations like in the English Channel. However, this will depend on the future development of other $\mathrm{NO}_{x}$ emission sources, too. These were not taken into account here, as has not been done for climate change either, in order to focus on shipping effects and facilitate the interpretation of emission changes in this sector. Because it can be expected that, in particular, land-based anthropogenic $\mathrm{NO}_{x}$ emissions in Europe will further decrease until 2030, the relative contribution of shipping emissions to $\mathrm{NO}_{2}$ and nitrate pollution levels in the North Sea area will be higher than demonstrated here. Ozone might increase in regions where it was found to decrease in scenarios No ECA and ECA SCR 16, namely in the English Channel. When this region, where ozone formation is currently VOC limited, turns into a $\mathrm{NO}_{x}$-limited region, $\mathrm{NO}_{x}$ emissions from shipping will enhance ozone concentrations in the entire study area. 
Appendix A: Supplementary information on other seasons and other pollutants

\section{A1 Sulfur-containing species in summer}

Reference

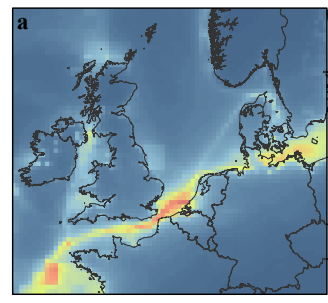

No ECA

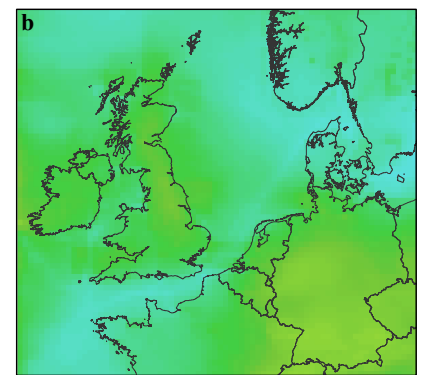

ECA SCR 16

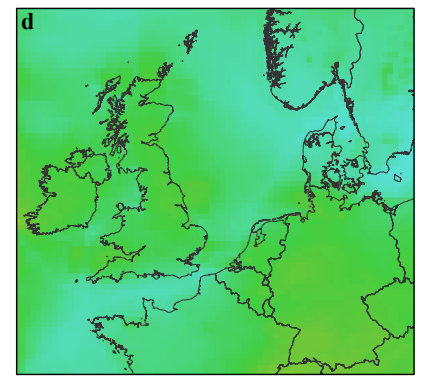

Change in $\mathrm{SO}_{2}$ concentration from ships, summer 2030

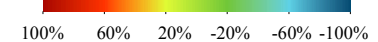

\section{ECA SCR 21}

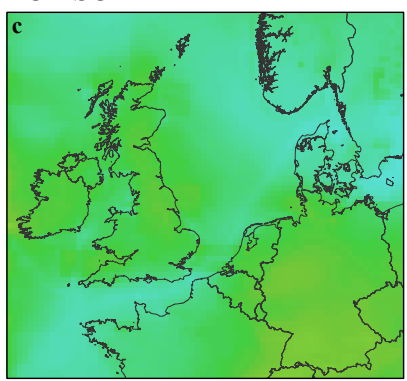

ECA opt

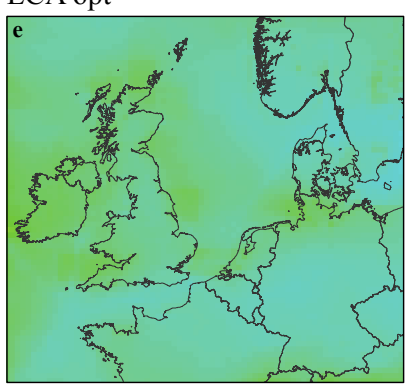

Reference

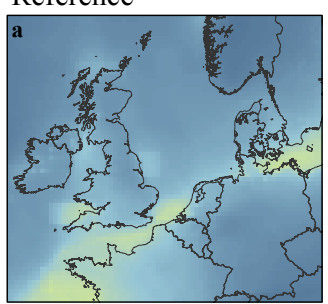

No ECA

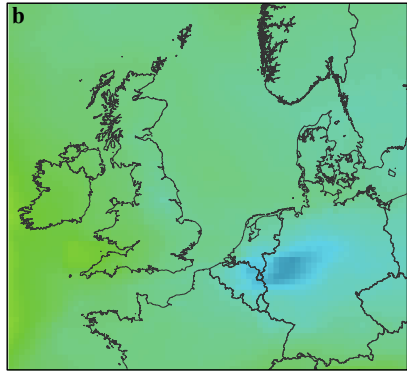

ECA SCR 16

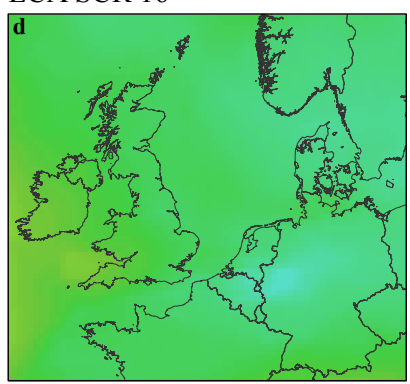

Change in $\mathrm{SO}_{4}$ concentration from ships, summer 2030

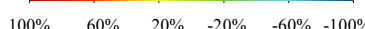$$
\begin{array}{lllll}
60 \% & 20 \% & -20 \% & -60 \% & -100 \%
\end{array}
$$

ECA SCR 21

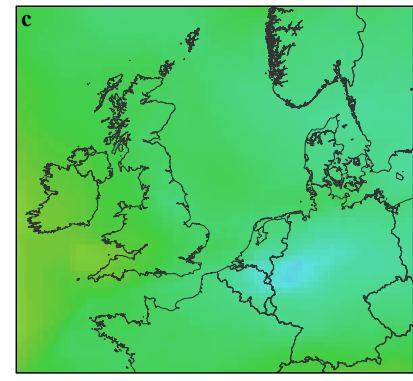

ECA opt

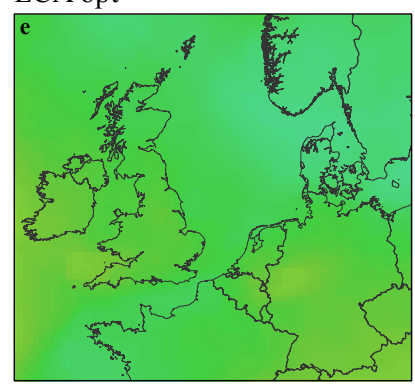

Figure A2. Change in the contribution of shipping to the total $\mathrm{SO}_{4}^{2-}$ concentrations in summer (JJA) compared to the reference case (a) for the scenarios (b) No ECA, (c) ECA SCR 16, (d) ECA SCR 21, and (e) ECA opt.

Figure A1. Change in the contribution of shipping to the total $\mathrm{SO}_{2}$ concentrations in summer (JJA) compared to the reference case (a) for the scenarios (b) No ECA, (c) ECA SCR 16, (d) ECA SCR 21, and (e) ECA opt. 


\section{A2 Contribution of shipping to air pollution in winter}

Reference
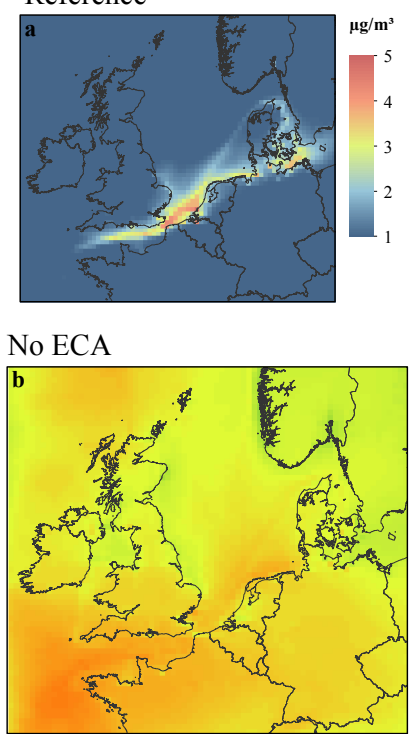

ECA SCR 16

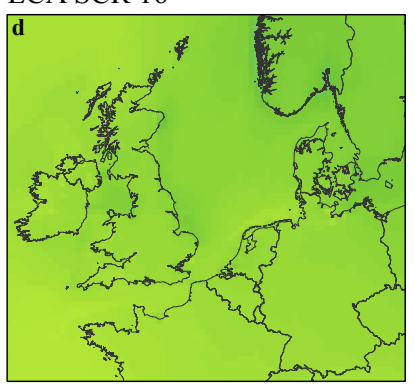

ECA SCR 21

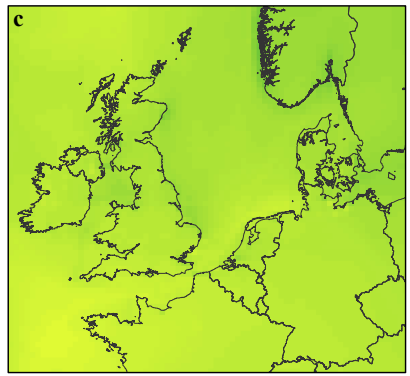

ECA opt

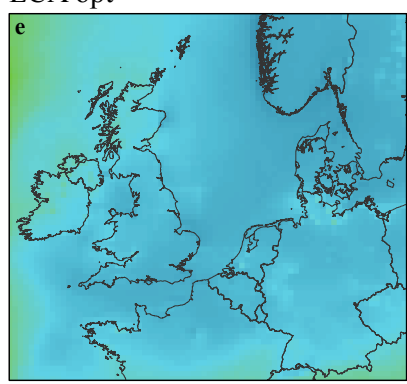

Figure A3. Change in the contribution of shipping to the total $\mathrm{NO}_{2}$ concentrations in winter (DJF) compared to the reference case (a) for the scenarios (b) No ECA, (c) ECA SCR 16, (d) ECA SCR 21, and (e) ECA opt.
Reference

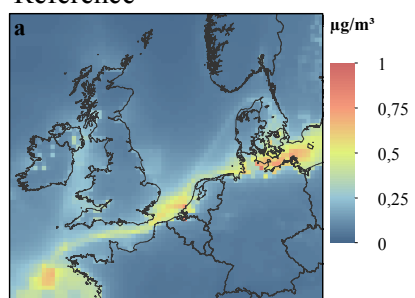

No ECA

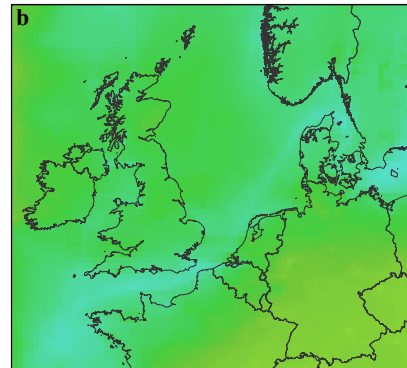

ECA SCR 16

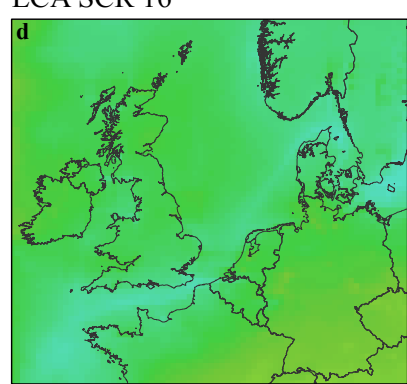

Figure A4. Change in the contribution of shipping to the total $\mathrm{SO}_{2}$ concentrations in winter (DJF) compared to the reference case (a) for the scenarios (b) No ECA, (c) ECA SCR 16, (d) ECA SCR 21, and (e) ECA opt.

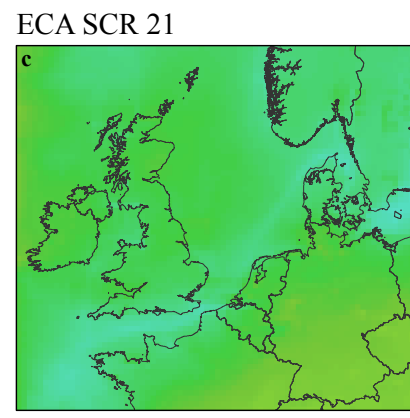

ECA opt

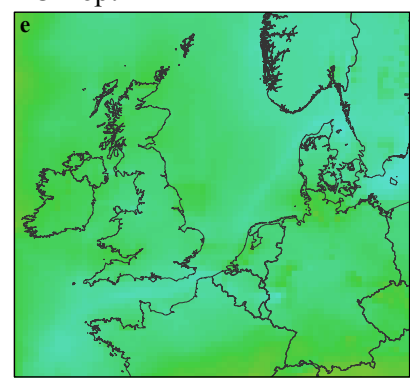

hange in $\mathrm{SO}_{2}$ concentration
from ships, winter 2030

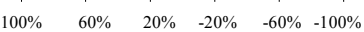




\section{Reference}

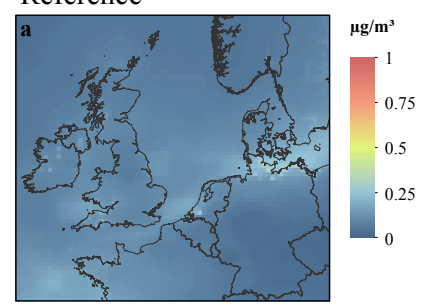

No ECA

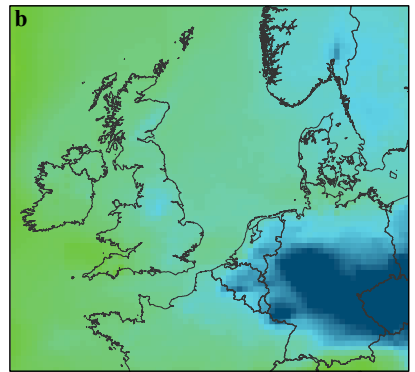

ECA SCR 16

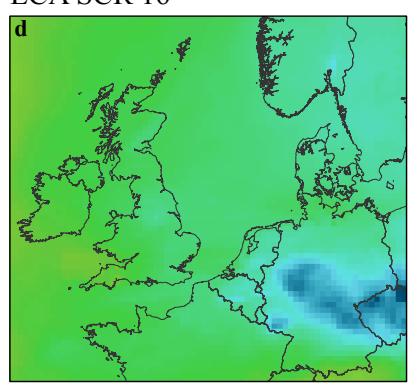

Change in $\mathrm{SO}_{4}$ concentration from ships, winter 2030

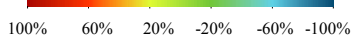

ECA SCR 21

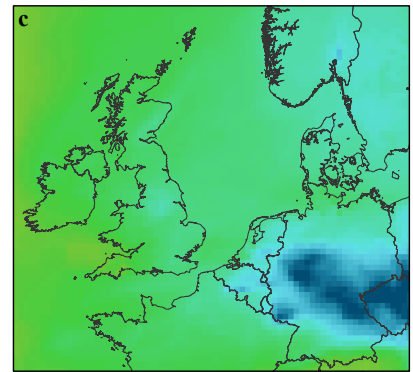

ECA opt

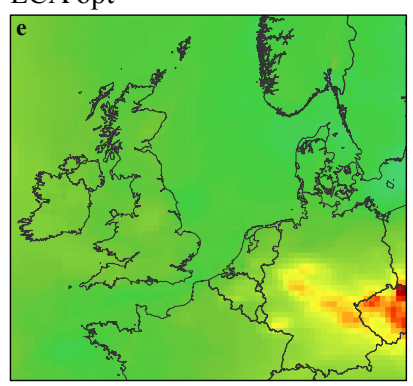

Figure A5. Change in the contribution of shipping to the total $\mathrm{SO}_{4}^{2-}$ concentrations in winter (DJF) compared to the reference case (a) for the scenarios (b) No ECA, (c) ECA SCR 16, (d) ECA SCR 21, and (e) ECA opt. 


\section{A3 Time series in selected areas}
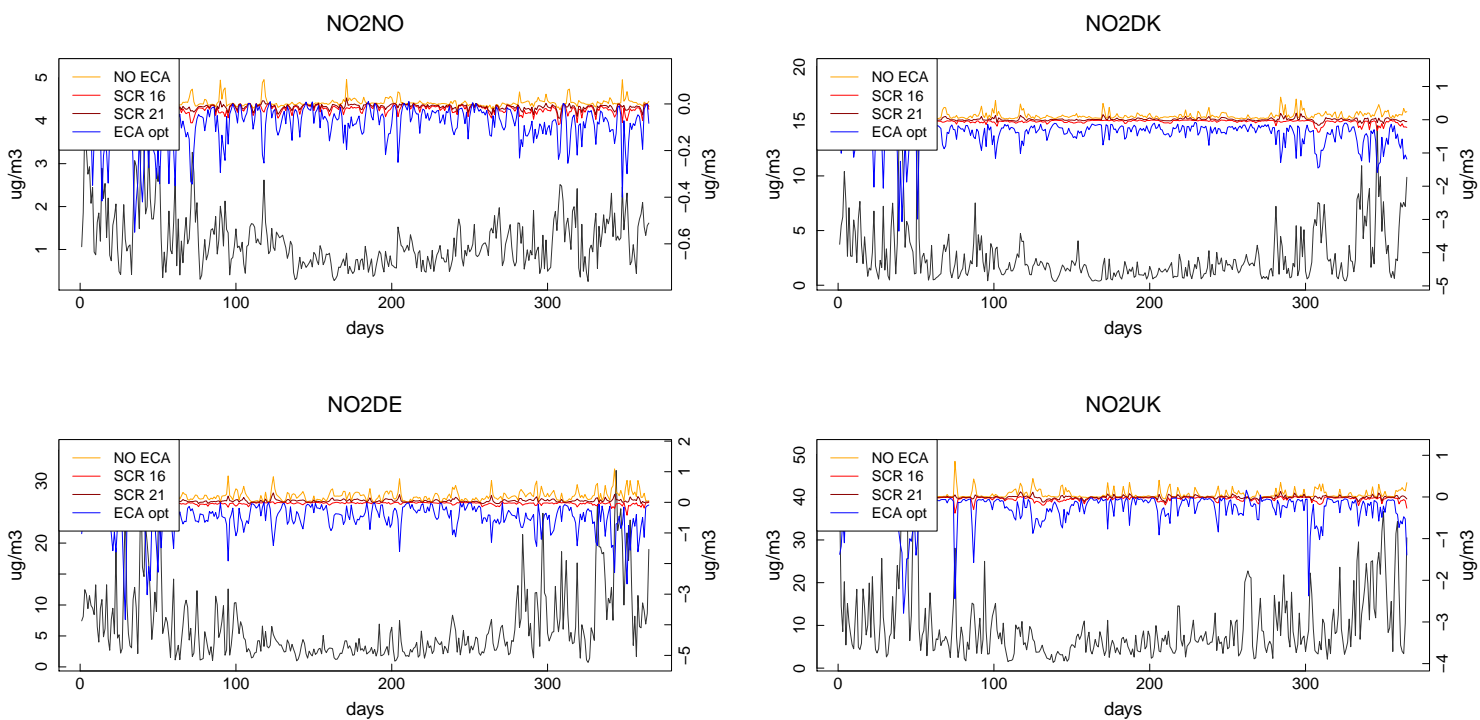

Figure A6. Time series of daily average $\mathrm{NO}_{2}$ concentrations in $\mu \mathrm{g} \mathrm{m}^{-3}$ (black, left $y$ axes) and change in the contribution of shipping to the $\mathrm{NO}_{2}$ concentrations in the coastal areas of Norway (region 1), Denmark (region 2), Germany (region 3), and Great Britain (region 5) for all scenarios (right $y$ axes).
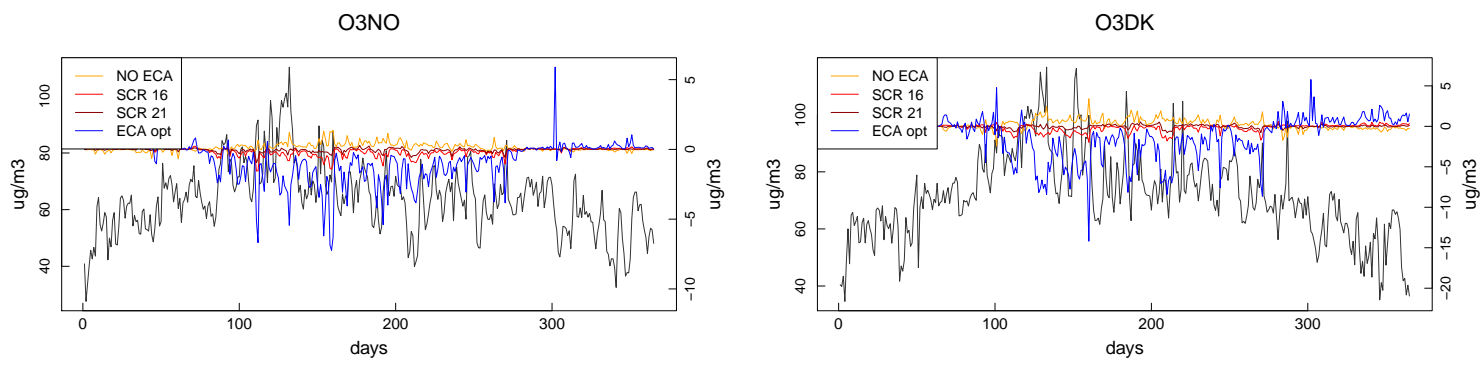

O3NL
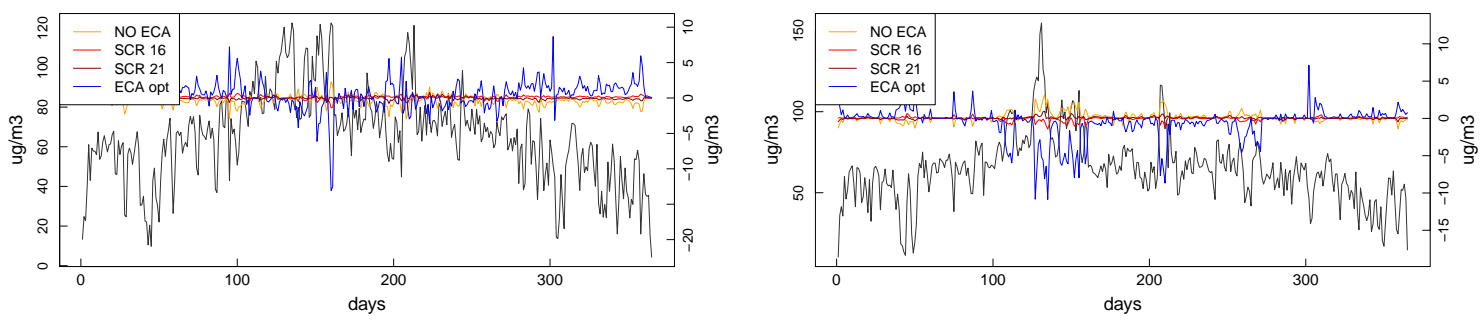

Figure A7. Time series of daily average $\mathrm{O}_{3}$ concentrations in $\mu \mathrm{g} \mathrm{m}^{-3}$ (black, left $y$ axes) and change in the contribution of shipping to the $\mathrm{O}_{3}$ concentrations in the coastal areas of Norway (region 1), Denmark (region 2), Belgium and the Netherlands (region 4), and Great Britain (region 5) for all scenarios (right $y$ axes). 
PM25NO

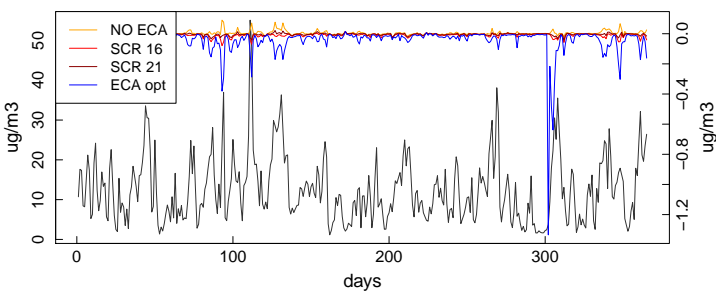

PM25NL

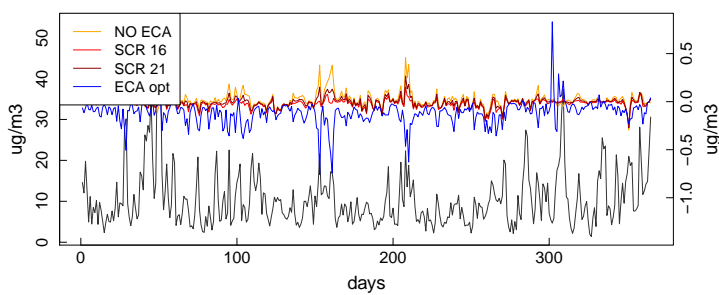

PM25DK

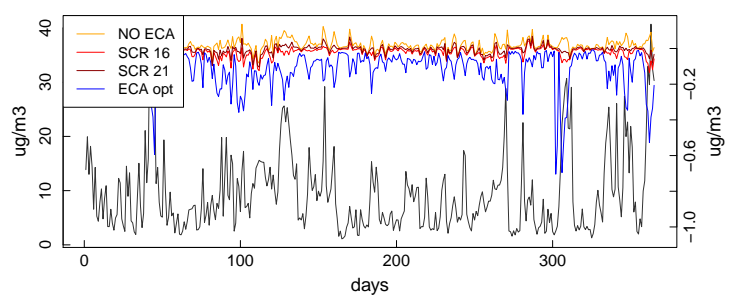

PM25UK

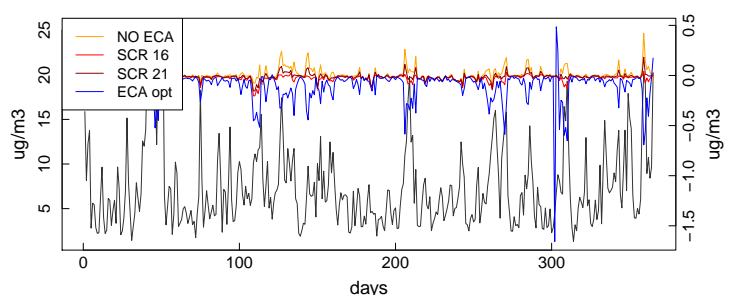

Figure A8. Time series of daily average $\mathrm{PM}_{2.5}$ concentrations in $\mu \mathrm{g} \mathrm{m}^{-3}$ (black, left $y$ axes) and change in the contribution of shipping to the $\mathrm{PM}_{2.5}$ concentrations in the coastal areas of Norway (region 1), Denmark (region 2), Belgium and the Netherlands (region 4), and Great Britain (region 5) for all scenarios (right $y$ axes). 
Acknowledgements. This work has partly been funded by the European Regional Development Fund (ERDF) within Interreg IVB projects Clean North Sea Shipping (CNSS) and CNSS Improved Dissemination and Impact (CNSS-IDI). We thank our colleagues from CNSS for their valuable comments concerning the development of the emission scenarios.

US EPA is gratefully acknowledged for the use of CMAQ; we thank Twan van Noije (KNMI) for providing TM5 model data.

The article processing charges for this open-access publication were covered by a Research Centre of the Helmholtz Association.

Edited by: A. Richter

\section{References}

Aulinger, A., Matthias, V., Zeretzke, M., Bieser, J., Quante, M., and Backes, A.: The impact of shipping emissions on air pollution in the greater North Sea region - Part 1: Current emissions and concentrations, Atmos. Chem. Phys., 16, 739-758, doi:10.5194/acp16-739-2016, 2016.

Bieser, J., Aulinger, A., Matthias, V., Quante, M., and Builtjes, P.: SMOKE for Europe - adaptation, modification and evaluation of a comprehensive emission model for Europe, Geosci. Model Dev., 4, 47-68, doi:10.5194/gmd-4-47-2011, 2011a.

Bieser, J., Aulinger, A., Matthias, V., Quante, M., and Denier van der Gon, H. A. C.: Vertical emission profiles for Europe based on plume rise calculations, Environ. Pollut., 159, 29352946, doi:10.1016/j.envpol.2011.04.030, 2011b.

Buhaug, Ø., Corbett, J., Endresen, Ø., Eyring, V., Faber, J., Hanayama, S., Lee, D., Lee, D., Lindstad, H., Markowska, A., Mjelde, A., Nelissen, D., Nilsen, J., Pålsson, C., Winebrake, J., Wu, W., and Yoshida, K.: Second IMO GHG Study, Tech. rep., International Maritime Organization (IMO), London, UK, 2009.

Byun, D. and Ching, J.: Science Algorithms of the EPA Models-3 Community Multiscale Air Quality Modeling System, Epa/600/r-99/030, US Environmental Protection Agency, Office of Research and Development, Washington DC, 1999.

Byun, D. and Schere, K.: Review of the Governing Equations, Computational Algorithms, and Other Components of the Models-3 Community Multiscale Air Quality (CMAQ) Modeling System, Appl. Mech. Rev., 59, 51-77, 2006.

Det Norske Veritas: DNV Report Shipping 2020, Tech. rep., DNV, Høvik, Norway, 2012.

Doms, G. and Baldauf, M.: A Description of the Nonhydrostatic Regional Model LM. Part I: Dynamics and Numerics., Tech. rep., Deutscher Wetterdienst, available at: http://www.cosmo-model. org/content/model/documentation/core/cosmoDyncsNumcs.pdf (last access: 29 October 2015), 2002.

Doms, G., Förstner, J., Heise, E., Herzog, H.-J., Mrionow, D., Raschendorfer, M., Reinhart, T., Ritter, B., Schrodin, R., Schulz, J.-P., and Vogel, G.: A Description of the Nonhydrostatic Regional COSMO Model, Part II: Physical Parameterization, Tech. rep., Deutscher Wetterdienst, available at: http://www.cosmo-model.org/content/model/documentation/ core/cosmoPhysParamtr.pdf (last access: 9 April 2014), 2011.
Edney, E. O., Kleindienst, T. E., Lewandowski, M., and Offenberg, J. H.: Updated SOA chemical mechanism for the Community Multi-Scale Air Quality model, Tech. Rep. EPA 600/X-07/025, US EPA, Research Triangle Park, NC, 2007.

European Union: Council Directive 1999/32/EC of 26 April 1999 relating to a reduction in the sulphur content of certain liquid fuels and amending Directive 93/12/EEC, available at: http://eur-lex.europa.eu/legal-content/EN/TXT/?uri=celex: 31999L0032 (last access: 31 August 2015), 1999.

European Union: Directice 2012/33/EU of the European Parliament and of the Council of 21 November 2012 amending Council Directive 1999/32/EC as regards the sulphur content of marine fuels, available at: http://eur-lex.europa.eu/legal-content/EN/TXT/ ?uri=celex:32012L0033 (last access: 31 August 2015), 2012

Eyring, V., Kohler, H. W., Lauer, A., and Lemper, B.: Emissions from international shipping: 2. Impact of future technologies on scenarios until 2050, J. Geophys. Res.-Atmos., 110, D17306, doi:10.1029/2004JD005620, 2005.

Foley, K. M., Roselle, S. J., Appel, K. W., Bhave, P. V., Pleim, J. E., Otte, T. L., Mathur, R., Sarwar, G., Young, J. O., Gilliam, R. C., Nolte, C. G., Kelly, J. T., Gilliland, A. B., and Bash, J. O.: Incremental testing of the Community Multiscale Air Quality (CMAQ) modeling system version 4.7, Geosci. Model Dev., 3, 205-226, doi:10.5194/gmd-3-205-2010, 2010.

Geyer, B.: High-resolution atmospheric reconstruction for $\mathrm{Eu}-$ rope 1948-2012: coastDat2, Earth Syst. Sci. Data, 6, 147-164, doi:10.5194/essd-6-147-2014, 2014.

Hammingh, P., Holland, M., Geilenkirchen, G., Jonson, J., and Maas, R.: Assessment of the environmental impacts and health benefits of a nitrogen emission control area in the North Sea, Tech. rep., PBL Netherlands Environmental Assessment Agency, The Hague, 2012.

Huijnen, V., Williams, J., van Weele, M., van Noije, T., Krol, M., Dentener, F., Segers, A., Houweling, S., Peters, W., de Laat, J., Boersma, F., Bergamaschi, P., van Velthoven, P., Le Sager, P., Eskes, H., Alkemade, F., Scheele, R., Nédélec, P., and Pätz, H.-W.: The global chemistry transport model TM5: description and evaluation of the tropospheric chemistry version 3.0, Geosci. Model Dev., 3, 445-473, doi:10.5194/gmd-3-445-2010, 2010.

International Maritime Organisation: Amendments to the Annex of the Protocol of 1997 to Amend the International Convention for the Prevention of Pollution from Ships, 1973, as Modified by the Protocol of 1978 Relating thereto (MARPOL Annex VI), (last access: 28 January 2015), 2008.

International Maritime Organisation, Marine Environment Protection Committee: http://www.imo.org/MediaCentre/ MeetingSummaries/MEPC/Pages/MEPC66.aspx (last access: 25 January 2015), 2014.

Jalkanen, J.-P., Johansson, L., Kukkonen, J., Brink, A., Kalli, J., and Stipa, T.: Extension of an assessment model of ship traffic exhaust emissions for particulate matter and carbon monoxide, Atmos. Chem. Phys., 12, 2641-2659, doi:10.5194/acp-12-26412012, 2012.

Kalnay, E., Kanamitsu, M., Kistler, R., Collins, W., Deaven, D., Gandin, L., Iredell, M., Saha, S., White, G., Woollen, J., Zhu, Y., Chelliah, M., Ebisuzaki, W., Higgins, W., Janowiak, J., Mo, K. C., Ropelewski, C., Wang, J., Leetmaa, A., Reynolds, R., Jenne, R., and Joseph, D.: The NCEP/NCAR 40-year reanalysis project, B. Am. Meteorol. Soc., 77, 437-471, 1996. 
Kelly, J. T., Bhave, P. V., Nolte, C. G., Shankar, U., and Foley, K. M.: Simulating emission and chemical evolution of coarse seasalt particles in the Community Multiscale Air Quality (CMAQ) model, Geosci. Model Dev., 3, 257-273, doi:10.5194/gmd-3257-2010, 2010.

Matthias, V., Quante, M., and Aulinger, A.: Determination of the optimum MM5 configuration for long term CMAQ simulations of aerosol bound pollutants in Europe, Environ. Fluid Mech., 9, 91-108, doi:10.1007/s10652-008-9103-6, 2009.

Matthias, V., Bewersdorff, I., Aulinger, A., and Quante, M.: The contribution of ship emissions to air pollution in the North Sea regions, Environ. Pollut., 158, 2241-2250, doi:10.1016/j.envpol.2010.02.013, 2010.

Ritter, B. and Geleyn, J. F.: A Comprehensive Radiation Scheme For Numerical Weather Prediction Models With Potential Applications In Climate Simulations, Mon. Weather Rev., 120, 303-325, doi:10.1175/15200493(1992)120<0303:ACRSFN>2.0.CO;2, 1992.

Rockel, B., Will, A., and Hense, A.: The Regional Climate Model COSMO-CLM(CCLM), Meteorol. Z., 17, 347-348, 2008.

Schättler, U., Doms, G., and Schraff, C.: A Description of the Nonhydrostatic Regional COSMO-Model Part VII: User's Guide, Tech. rep., Deutscher Wetterdienst, 2008.

Schrodin, R. and Heise, E.: The multi-layer-version of the DWD soil model TERRA/LM, Consortium for Small-Scale Modelling (COSMO) Tech. Rep, 2, 16, 2001.
Seifert, A. and Beheng, K. D.: A double-moment parameterization for simulating autoconversion, accretion and selfcollection, Atmospheric Research, 59, Int Union Geodesy \& Geophys, ICCP, IAMAS, doi:10.1016/S0169-8095(01)00126-0, 2001.

Seifert, A. and Beheng, K. D.: A two-moment cloud microphysics parameterization for mixed-phase clouds, Part 1: Model description, Meteorol. Atmos. Phys., 92, 45-66, 2006.

Smith, T. W. P., Jalkanen, J. P., Anderson, B. A., Corbett, J. J., Faber, J., Hanayama, S., O’ Keeffe, E., Parker, S., Johansson, L., Aldous, L., Raucci, C., Traut, M., Ettinger, S., Nelissen, D., Lee, D. S., Ng, S., Agrawal, A., Winebrake, J. J., Hoen, M., Chesworth, S., and Pandey, A.: Third IMO GHG Study 2014, Tech. rep., International Maritime Organization (IMO), London, UK, 2014.

Steppeler, J., Doms, G., Schättler, U., Bitzer, H. W., Gassmann, A., Damrath, U., and Gregoric, G.: Meso-gamma scale forecasts using the nonhydrostatic model LM, Meteorol. Atmos. Phys., 82, 75-96, doi:10.1007/s00703-001-0592-9, 2003.

Tiedtke, M.: A Comprehensive Mass Flux Scheme For Cumulus Parameterization In Large-scale Models, Mon. Weather Rev., 117, 1779-1800, doi:10.1175/15200493(1989)117<1779:ACMFSF>2.0.CO;2, 1989. 